bioRxiv preprint doi: https://doi org/10.1101/2022 02 24.481814 * this version posted February 24,2022 . The copyright holder for this preprint (which was not certified by peer review) is the author/funder, who has granted bioRxiv a license to display the preprint in perpetuity. It is made available under aCC-BY-ND 4.0 International license.

\title{
LUBAC is required for RIG-I sensing of RNA viruses
}

Running title: Roles of HOIP, HOIL-1 and SHARPIN in antiviral immunity

Helena C Teague ${ }^{1}$, Charlotte Lefevre ${ }^{1}$, Eva Rieser ${ }^{2,3}$, Diego de Miguel $^{2,3}$, Daniel Patricio ${ }^{4}$, Marisa Oliveira ${ }^{1}$, Daniel S Mansur ${ }^{4}$, Nerea Irigoyen ${ }^{1}$, Henning Walczak ${ }^{2,3}$, and Brian J Ferguson ${ }^{1^{*}}$

${ }^{1}$ Department of Pathology, University of Cambridge, Tennis Court Road, Cambridge, UK

${ }^{2}$ Centre for Cell Death, Cancer and inflammation (CCCI), UCL Cancer Institute, 72 Huntley Street, University College London, London, UK

${ }^{3}$ Centre for Biochemistry, Medical Faculty, Joseph-Stelzmann-Str. 52, University of Cologne, Cologne, Germany

${ }^{4}$ Departamento de Microbiologia, Imunologia e Parasitologia, Centro de Ciências Biológicas, Universidade Federal de Santa Catarina (UFSC), Florianópolis, SC, Brazil

*Corresponding author: bf234@cam.ac.uk 


\begin{abstract}
The ability of cells to mount an interferon response to virus infections depends on intracellular nucleic acid sensing pattern recognition receptors (PRRs). RIG-I is an intracellular PRR that binds short double stranded viral RNAs to trigger MAVS-dependent signalling. The RIG-I/MAVS signalling complex requires the coordinated activity of multiple kinases and E3 ubiquitin ligases to activate the transcription factors that drive type I and type III interferon production from infected cells. The linear ubiquitin chain assembly complex (LUBAC) regulates the activity of multiple receptor signalling pathways in both ligase-dependent and -independent ways. Here, we show that the three proteins that constitute LUBAC have separate functions in regulating RIG-I signalling. Both HOIP, the E3 ligase capable of generating M1-ubiquitin chains, and LUBAC accessory protein HOIL-1 are required for viral RNA sensing by RIG-I. The third LUBAC component, SHARPIN, is not required for RIG-I signalling. These data cement the role of LUBAC as a positive regulator of RIG-I signalling and as an important component of antiviral innate immune responses.
\end{abstract}

\title{
Introduction
}

The interferon (IFN) response is a potent method of restricting virus replication at the site of infection. The ability of cells in infected tissues to rapidly detect invading viruses and mount an IFN response is a critical determinant of the outcome of viral disease ${ }^{1}$. Many RNA viruses are sensed by the intracellular pattern recognition receptor (PRR) retinoic-acid induced gene-I (RIG-I), which shows binding preference for short, double stranded hairpin RNAs with a 5' triphosphate group ${ }^{2,3}$. Upon ligand binding, RIG-I oligomerises via its caspase recruitment domains (CARDs) and binds the adaptor mitochondrial antiviral-signalling protein (MAVS) ${ }^{4}$. The oligomerisation of RIG-I and MAVS at the mitochondrial membrane leads to the formation of a large multi-protein signalling complex that co-ordinates RIG-I signalling outcomes ${ }^{5}$. The key output of RIG-I signalling is the transcription of IFN-I/III, cytokines and chemokines driven by the activation of the transcription factors nuclear factor-kappa B (NF-KB) and interferon regulatory factor 3 (IRF3) at the RIG-I/MAVS signalling complex (SC) ${ }^{6}$. 
bioRxiv preprint doi: https://doi.org/10.1101/2022.02.24.481814; this version posted February 24, 2022. The copyright holder for this preprint (which was not certified by peer review) is the author/funder, who has granted bioRxiv a license to display the preprint in perpetuity. It is made available under aCC-BY-ND 4.0 International license.

Regulated assembly of the RIG-I/MAVS SC requires the coordinated activity of E3 ubiquitin ligases and kinases that ultimately recruit and activate NF-KB and IRF3 $3^{5,7,8}$. IRF3 is activated by phosphorylation by the kinases TBK1 and IKKE, allowing phospho-IRF3 dimerisation and translocation to the nucleus ${ }^{9}$. NF-KB is activated by IKK complex-dependent phosphorylation and subsequent degradation of the inhibitor protein $\mathrm{I} \mathrm{KB} \alpha$. This step releases active NF-kB allowing it to translocate to the nucleus. Active, nuclear NF-KB and IRF3 co-ordinate a IFN$\mathrm{I} / \mathrm{III}$ and inflammatory transcriptional signature by binding to the promoters of specific genes, either independently or in tandem ${ }^{10}$. During this process, activation and modification of multiple and likely redundant TRAF proteins, K63-chain generating E3 ligases, results in the recruitment of the IKK complex via the ubiquitin binding-domain of NEMO $(\text { IKK } \gamma)^{7,11}$. TBK1 and IKKE are subsequently recruited, possibly independently and by mechanisms that involve binding to ubiquitinated proteins in the complex, resulting in IRF3 phosphorylation. The IKK complex phosphorylates IKB $\alpha$ and recruits the K48-chain E3 ligase $\beta$-TRCP to modify $\mathrm{p} \mid \mathrm{KB} \alpha$, tagging it for degradation.

The linear ubiquitin chain assembly complex (LUBAC) is responsible for attaching M1 ubiquitin chains to target proteins ${ }^{12}$. LUBAC consists of three proteins, HOIL-1-interacting protein (HOIP), which encodes the M1-chain E3 ligase activity; Heme-oxidised IRP2 Ubiquitin ligase-1 (HOIL-1); and Shank-associated RH domain-interacting protein (SHARPIN) ${ }^{13}$. M1 ubiquitin chains regulate multiple immune signalling pathways ${ }^{13}$ and LUBAC is recruited to a number of receptor signalling complexes, including the TNFR1-SC ${ }^{14}$ and TLR3-SC ${ }^{15}$. LUBAC'S function in RIG-I signalling is unclear, with studies indicating that it positively, negatively and redundantly regulates RIG-I signalling outputs ${ }^{7,16-20}$. In this study we set out to identify the contribution of the individual LUBAC components and the E3 ligase activity of LUBAC to the antiviral innate immune response downstream of RIG-I. We establish here specific roles for the individual LUBAC components in RIG-I signalling and show that whilst HOIP and HOIL-1 are essential for RNA-virus driven interferon responses, SHARPIN is not. 


\section{Materials and Methods}

\section{Cells}

All cell lines were grown in Dulbecco's Modified Eagle's Medium (DMEM) with 4.5 g/L Dglucose, $8 \mathrm{mM}$ L-glutamine and Sodium Pyruvate (Gibco), supplemented with $10 \%$ foetal calf serum (FCS, Pan Biotech) and $100 \mathrm{U} / \mathrm{mL}$ Penicillin and Streptomycin (Gibco). Cells were incubated at $37^{\circ} \mathrm{C}, 5 \% \mathrm{CO} 2$ and $3 \% \mathrm{O} 2$ in a humidified incubator.

\section{CRISPR/Cas9 editing}

The human genomic sequences of DDX58 (encoding RIG-I) and SHARPIN were identified on ENSEMBL (http://www.ensembl.org/index.html: DDX58 (RIG-I) ENSG00000107201 and SHARPIN ENSG00000179526). Small guide (sg)RNAs were designed using Benchling (www.benchling.com). sgRNA sequences were DDX58: AAAGTCCAGAATAACCTGCA and SHARPIN: CCTAGTCCGAGGTGCCACCG. Guides were synthesised as forward and reverse complementary DNA oligonucleotides (IDT) with Bbsl restriction sites, to enable annealing into the pSpCas9(BB)-2A-GFP (PX458) plasmid (Addgene \#48138). A549 cells were transfected with PX458-containing plasmids and single-cells sorted by GFP positivity to generate clonal knockout (KO) lines. Successful KO's were verified by immunoblotting.

\section{Viruses}

SeV Cantell strain and Zika virus ZIKV/H.Sapiens/Brazil/PE243/2015 (ZIKV PE243) were used for infection experiments. To quantify ZIKV by plaque assay, samples were 10 -fold serial diluted in serum-free DMEM. $400 \mu \mathrm{L}$ of dilutions were added to Vero cells in duplicate and incubated for 1 hour at $37^{\circ} \mathrm{C}$. The inoculum was removed and replaced with a 50:50 mix of 3\% LMP agarose and 2x MEM 4\% FCS. Cells were incubated for 5 days before being fixed overnight at room temperature using formal saline ( $4 \%$ formaldehyde, $0.9 \%$ sodium chloride, 90\% $\mathrm{H} 2 \mathrm{O}$ ) and then stained with Toluidine Blue and plaques counted.

\section{RT-qPCR}

RNA was extracted from treated cells with $250 \mu \mathrm{L}$ lysis buffer and purified by spin column or phenol/chloroform extraction. 500 ug purified RNA was used for cDNA synthesis by Superscript III Reverse Transcriptase (Invitrogen). cDNA was diluted 1:3 in nuclease-free 
bioRxiv preprint doi: https://doi.org/10.1101/2022.02.24.481814; this version posted February 24, 2022. The copyright holder for this preprint (which was not certified by peer review) is the author/funder, who has granted bioRxiv a license to display the preprint in perpetuity. It is made available under aCC-BY-ND 4.0 International license.

water (Ambion) and added to $5 \mu \mathrm{L}$ SyGreen HiROX mix (PCR Biosystems) in 384 well plates with $0.5 \mu \mathrm{M}$ forward and reverse primers (sequences in Supplementary table 1) run on a Viia7 Real-Time PCR machine (Thermo Scientific). Fold induction of the target gene was calculated relative to GAPDH in human cells and Hprt in murine cells.

\section{Immunoblotting}

Whole cell lysates were prepared by lysing in approximately $100 \mu \mathrm{L}$ per $2.5 \times 10^{6}$ cells. The lysis buffer used for A549 was radioimmunoprecipitation assay (RIPA) buffer (50 mM Tris$\mathrm{HCl} \mathrm{pH} \mathrm{8,1 \%} \mathrm{Nonidet} \mathrm{P-40} \mathrm{(NP-40),} \mathrm{0.5 \%} \mathrm{sodium} \mathrm{deoxycholate,} \mathrm{0.1 \%} \mathrm{SDS,} 150 \mathrm{mM} \mathrm{NaCl}$ ) and for murine embryonic fibroblasts (MEFs) was $30 \mathrm{mM}$ Tris- $\mathrm{HCl} \mathrm{pH} 7.4,1 \%$ Triton X-100, $20 \mathrm{mM} \mathrm{NaCl}, 2 \mathrm{mM} \mathrm{KCl}, 2 \mathrm{mM}$ EDTA and 10\% glycerol with protease inhibitors (Roche) and phosphatase inhibitors (Sigma) where appropriate. Protein concentration was determined by bicinchoninic acid (BCA) assay (Thermo Scientific) to enable equal loading of protein samples. Gels were run in a Mini-PROTEAN system (BioRad), transferred onto nitrocellulose membrane and analysed with specific primary and secondary antibodies listed in Supplementary Table 2.

\section{ELISA}

A DuoSetELISA assay (R\&D) was used to detect the presence of human CXCL10/IP-10 in the supernatants of infected or stimulated A549 cells using TMB (Abcam) as the substrate solution and $0.3 \mathrm{M} \mathrm{H}_{2} \mathrm{SO}_{4}$ as the stop solution.

\section{Flow cytometry}

Cells were washed twice in PBS, detached with trypsin and resuspended in DMEM 2.5\% FCS. Cells were pelleted by centrifugation at $600 \times \mathrm{g}$ for 6 minutes and fixed in $100 \mu \mathrm{L}$ per $1 \times 10^{6}$ cells of PhosFlow Lyse/Fix buffer (BD Bioscience) at $37{ }^{\circ} \mathrm{C}$ for 10 minutes. Fixation was stopped by addition of $1 \mathrm{~mL}$ of PBS $1 \%$ FCS and cells were stored at $4{ }^{\circ} \mathrm{C}$ overnight in PBS. Cells were pelleted by centrifugation and further fixed and permeabilised in $1 \mathrm{~mL}$ of $88 \%$ methanol PBS at $4{ }^{\circ} \mathrm{C}$ for 30 minutes. Cells were washed 3 times in PBS $1 \%$ FCS, each time pelleted by centrifugation at $850 \times \mathrm{g}$ for 6 minutes at $4{ }^{\circ} \mathrm{C}$. Cells were incubated with primary antibody diluted in PBS $1 \%$ FCS $\left(25 \mu \mathrm{L}\right.$ per $1 \times 10^{6}$ cells), for 1 hour at room temperature in the dark. Details of antibodies are in Supplementary Table 3. The washing steps were 
bioRxiv preprint doi: https://doi.org/10.1101/2022.02.24.481814; this version posted February 24, 2022. The copyright holder for this preprint (which was not certified by peer review) is the author/funder, who has granted bioRxiv a license to display the preprint in perpetuity. It is made available under aCC-BY-ND 4.0 International license.

repeated, and cells were resuspended in filtered PBS in FACS tubes and stored at $4^{\circ} \mathrm{C}$ until analysis. Control samples, no antibody, single antibody and positive control samples, were also stained under the same conditions. Samples were analysed by flow cytometry using an Attune NxT Acoustic Focusing Cytometer (Fisher Scientific) and analysed in FlowJo Version 10.

\section{Viability assay}

To quantify cell viability, a Nucleocounter NC-250 Vitality assay was used. Cells were washed twice with PBS, trypsinised and resuspended in DMEM 2.5\% FCS to a total volume of $1 \mathrm{~mL}$ per $5 \times 105$ cells ( 1 well). The cell suspension was mixed with NC-250 Solution 6 , containing VB-48 vitality dye and propidium iodide (PI), at a 20:1 dilution, and this was added to a NCslide. Slides were loaded into the Nucleocounter NC-250 and PI / VB-48 fluorescence intensity was quantified to analyse cell viability.

\section{Co-Immunoprecipitation}

A549 cells stably expressing tandem affinity purification (TAP)-tagged HOIP or NEMO reintroduced into their respective KO lines, were seeded in $15 \mathrm{~cm}$ dishes. Cells were stimulated with $100 \mathrm{U} / \mathrm{mL}$ IFN $\alpha$ and incubated for 24 hours before being infected with SeV for the indicated time. Cells were washed twice in $5 \mathrm{~mL}$ cold PBS and scraped in $0.5 \mathrm{~mL}$ lysis buffer $1(100 \mathrm{mM} \mathrm{NaCl}, 40 \mathrm{mM}$ Tris- $\mathrm{HCl}, \mathrm{pH} 7.5,1 \mathrm{mM} \mathrm{CaCl} 2,1 \mathrm{mM} \mathrm{MgCl}$ ) with protease inhibitors (Roche) and phosphatase inhibitors (Sigma). Cells were lysed for 30 minutes on ice and 40 minutes on a rotating wheel at $4{ }^{\circ} \mathrm{C}$. Insoluble debris was pelleted by centrifugation at $16200 \times \mathrm{g}$ for 10 minutes at $4{ }^{\circ} \mathrm{C}$ and cleared lysate was transferred to a new Eppendorf tube. Pellets were resuspended in $0.5 \mathrm{~mL}$ lysis buffer $2(100 \mathrm{mM} \mathrm{NaCl}, 40 \mathrm{mM}$ Tris- $\mathrm{HCl}, \mathrm{pH}$ 7.5, $1 \mathrm{mM} \mathrm{CaCl}$, $1 \mathrm{mM} \mathrm{MgCl}$ 2, $1 \%$ Triton $\mathrm{X}-100$ and $0.1 \%$ SDS) with protease inhibitors (Roche) and phosphatase inhibitors (Sigma) and twice subjected to sonication at $20 \mathrm{~Hz}$ for 10 seconds, with a minute on ice between. Sonicated samples were subjected to centrifugation at $16200 \times \mathrm{g}$ for 20 minutes at $4{ }^{\circ} \mathrm{C}$. Cleared lysates from pre- and postsonification were combined. $35 \mu \mathrm{L}$ of cleared lysate was taken for an input sample and $7 \mu \mathrm{L}$ of $6 x$ loading buffer was added to the remainder. $25 \mu \mathrm{L}$ per sample of Flag-M2 beads (Sigma), pre-washed once with PBS and 3 times with the respective lysis buffer, were added to the cleared lysates and this was incubated on a rotating wheel at $4{ }^{\circ} \mathrm{C}$ for 16 hours. Beads 
bioRxiv preprint doi: https://doi org/10.1101/2022 $0224.481814 \cdot$ this version posted February 24, 2022. The copyright holder for this preprint (which was not certified by peer review) is the author/funder, who has granted bioRxiv a license to display the preprint in perpetuity. It is made available under aCC-BY-ND 4.0 International license.

were pelleted by centrifugation at $2,400 \times \mathrm{g}$ for 5 minutes at $4{ }^{\circ} \mathrm{C}$ and unbound material was removed using a $1 \mathrm{~mL}$ needle with a 20 -gage syringe. Beads were washed by addition of 1 $\mathrm{mL}$ of respective lysis buffer (without protease or phosphatase inhibitors) followed by centrifugation as before. The washing procedure was repeated four more times. $40 \mu \mathrm{L}$ of $2 \mathrm{x}$ loading buffer with $330 \mathrm{mM}$ DTT was added to beads. Immunoprecipitation samples were heated at $95^{\circ} \mathrm{C}$ for 5 minutes and were analysed by Western blotting.

\section{Immunofluorescence staining}

A549 (WT and HOIP-/-) cells were seeded onto a $13 \mathrm{~mm}$ cover slips in 24-wells plates overnight, followed by ZIKV infection for 24 hours or $100 \mathrm{ng} / \mathrm{mL}$ TNF stimulation for 30 minutes. Cells were then fixed in 3\% paraformaldehyde for 20 minutes and permeabilizated with $0.1 \%$ Triton $\mathrm{X}-100$ diluted in blocking buffer ( $2 \%$ bovine serum albumin in PBS) for 5 minutes. Primary and secondary antibodies (listed in Supplementary table 4) were diluted in blocking buffer. Cells were incubated with primary and then secondary antibodies for 1 hour. Samples were washed in PBS between each step. Images were acquired on an Olympus BX41 microscope. 


\section{Results}

\section{RIG-I is the dominant RNA sensor in A549 cells}

To help define the outputs of RIG-I activation and its signalling mechanisms, we first generated a RIG-I knockout A549 cell line using CRISPR/Cas9 editing (Fig. 1A). Infection of wild type (WT) A549 cells with Sendai virus (SeV) or Zika virus (ZIKV) resulted in robust IFN-I (IFNB1) and IFN-III (IFNL1) transcription and activation of both IRF3-dependent (ISG54) ${ }^{21}$ and NF-KB-dependent (NFKBIA) ${ }^{22}$ genes (Fig. 1). In SeV- and ZIKV-infected RIG-I KO cells there was an almost complete loss of IFN-I and IFN-III response and a failure to transcribe other IRF3 and NF-KB dependent genes (Fig. 1 B, C). The response to the RIG-I specific ligand 3phpRNA was also lost in RIG-I KO cells (Fig. 1D), although the IFN-response to this ligand was weak, possibly due to low transfection efficiency. The transcriptional response to transfection of the dsRNA mimetic poly(I:C) was also abrogated in RIG-I KO cells (Fig. 1E). Since poly $(\mathrm{I}: \mathrm{C})$ can be sensed intracellularly by both RIG-I and MDA5 as well as by TLR3 in endosomes, the loss of poly(I:C)-driven transcription in RIG-I KO cells suggested that little or no MDA5 or TLR3 activity is present in A549.

\section{HOIP is required for anti-viral RIG-I signalling and for the IFN response to RNA viruses}

Since the transcriptional response to SeV, ZIKV and intracellular synthetic RNAs was found to be dependent on RIG-I, we used this system to define the contribution of the E3 ligase HOIP to RIG-I signalling. In CRISPR/Cas9-generated HOIP KO A549 cells infected with SeV, transcription of IFNB and IFNL was $>95 \%$ reduced compared to infected WT cells, indicating that HOIP is essential for the IFN-I and IFN-III responses to RNA virus infection (Fig. 2A). The loss of RIG-I dependent gene activation in HOIP KO cells extended to significant reductions in CXCL10 and ISG15, as well as ISG54 and NFKBIA transcription, indicating that both IRF3 and NF-KB-dependent responses to SeV were significantly impaired by loss of HOIP (Fig. 2A). Similar loss of transcription was observed in response to RNA transfection in HOIP KO cells (Fig. 2B). Analysis of intracellular signalling events showed that the activation of IRF3 and NF-KB signalling triggered by SeV infection in WT A549 cells was impaired in HOIP KO cells (Fig. 2C). TBK1, IRF3 and IKB $\alpha$ phosphorylation were all reduced at 2 and $4 \mathrm{~h}$ post infection, confirming that HOIP is required for the complete activation of both IRF3 and NF-KB 
bioRxiv preprint doi: https://doi.org/10.1101/2022.02.24.481814; this version posted February 24, 2022. The copyright holder for this preprint (which was not certified by peer review) is the author/funder, who has granted bioRxiv a license to display the preprint in perpetuity. It is made available under aCC-BY-ND 4.0 International license.

pathways downstream of RIG-I signalling. HOIP KO cells were also defective in virus- and RNA-driven CXCL10 secretion (Fig. 2D), indicating loss of HOIP results in the overall loss of RIG-I signalling.

As well as IFN responses, RIG-I signalling can result in regulated cell death ${ }^{23,24}$, therefore we quantified apoptotic and non-apoptotic death following SeV infection in WT and HOIP KO cells. Using phosFlow, we confirmed a reduction in phospho-IRF3 levels in HOIP KO cells compared to WT, but only observed active caspase-3 in $2 \%$ of cells during infection (Supplementary Fig. S1A). The lack of RIG-I driven caspase activation was corroborated by quantifying cell viability after infection. Cells infected with SeV showed $\sim 10 \%$ cell death in comparison with $\sim 70 \%$ cell death following staurosporine treatment, with no significant difference between WT and HOIP KO cells (Supplementary Fig. S1B). As such, in A549 cells RIG-I was not found to activate a regulated cell death pathway, irrespective of the presence or absence of HOIP.

To assess the impact of HOIP on infection with a replicating RNA virus, we infected WT and HOIP KO cells with ZIKV. IFNB and IFNL transcription was almost abrogated in HOIP KO cells compared to WT and there was an $80 \%$ reduction in CXCL10 transcription (Fig. $3 \mathrm{~A}$ ). This defective transcriptional response was not a result of loss of infectivity or replicative capacity of ZIKV in HOIP KO cells as the virus titres and E protein expression levels were not impacted by loss of HOIP (Fig. 3B, C). We also assessed the impact of HOIP loss on IRF3 and NF-KB P65 nuclear translocation during ZIKV infection. In WT infected cells P65 and IRF3 were found translocated to the nucleus in multiple ZIKV infected cells. This translocation was lost in HOIP KO cells, consistent with the loss of cytoplasmic RIG-I signalling (Fig. 3D, E). HOIP is therefore essential for the transcriptional outputs of RIG-I signalling and for the IRF3 and NF-KB dependent IFN-I/III response to RNA virus infections.

\section{HOIL-1 is required for anti-viral RIG-I signalling}

To understand the function of HOIL-1 in RIG-I signalling we initially attempted to create HOIL-1 KO A549 cells but failed to isolate knockout clones. We instead used MEFs, completely deficient in HOIL-1 expression (Supplementary Fig. S2). As complete HOIL-1 KO is embryonically lethal in mice, but can be partially rescued by backcrossing to TNF $\mathrm{KO}^{25}$, we 
bioRxiv preprint doi: https://doi.org/10.1101/2022.02.24.481814; this version posted February 24, 2022. The copyright holder for this preprint (which was not certified by peer review) is the author/funder, who has granted bioRxiv a license to display the preprint in perpetuity. It is made available under aCC-BY-ND 4.0 International license.

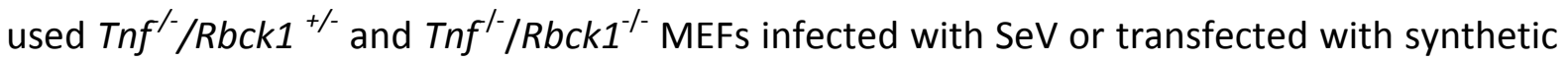
RNAs. MEFs lacking HOIL-1 were found to be defective in RIG-I-driven IFN-I transcription and activation of both IRF3 and NF-KB signalling after SeV infection (Fig. 4A, B). Following RNA transfection, Ifnb, Cxcl10, Isg54, Isg15, Nfkbia and I/6 transcription were also significantly reduced in HOIL-1 KO MEFs (Fig. 4C, D). This data defines HOIL-1, along with HOIP, as a key component of RIG-I signalling and indicates that LUBAC's positive regulation of RIG-I signalling is conserved between human and murine cells.

\section{SHARPIN is not required for anti-viral RIG-I signalling}

The third LUBAC component, SHARPIN, has no ligase activity and acts as a structural protein, co-ordinating LUBAC and its interactions with other protein complexes ${ }^{26}$. To analyse the impact of SHARPIN on RIG-I signalling, we used two systems. We generated a SHARPIN KO A549 cell line (Fig. 5), and also used $c p d m$ MEFs, which contain a germline mutation in the murine Sharpin gene that results in complete loss of SHARPIN protein expression ${ }^{26}$. Infection of SHARPIN KO A549 cells resulted in increased RIG-I-driven gene activation compared to WT cells, with interferon transcription as well as IRF3 and NF-KB-dependent gene transcription all increased in KO cells (Fig. 5A). In response to RNA transfection there was no significant alteration in CXCL10 transcription, but a significant reduction in ISG15 transcription (Fig. 5B) Analysis of the intracellular signalling events indicated that loss of SHARPIN did not impact TBK1, IRF3 or IKB $\alpha$ phosphorylation following SeV infection (Fig. 5C), but the increase in RIG-I signalling output is also observed at the level of CXCL10 protein secretion (Fig. 5D). Infection of $c p d m$ MEFs, lacking SHARPIN expression (Supplementary Fig. S3A), with SeV resulted in a slight reduction in NF-kB-dependent genes, but increased IRF3-dependent transcription (Supplementary Fig. S3B). Transfection with RIG-I-specific RNA ligand, however, showed no impact of SHARPIN expression on RIG-I-driven transcription (Supplementary Fig. S3C). Poly(I:C)-driven transcription was impaired in $c p d m$ MEFs (Supplementary Fig. S3D), although this might be explained by interference from active TLR3 or MDA5 signalling in MEFs ${ }^{15}$. Overall there was clear evidence that SHARPIN is not required for RIG-I signalling in humans or mice, and evidence that SHARPIN loss results in increased IRF3-dependent transcription under certain conditions. Comparison of the relative contribution of the three separate LUBAC components therefore defines both HOIP and 
bioRxiv preprint doi: $h$ ttps://doi.org/10.1101/2022.02.24.481814; this version posted February 24, 2022. The copyright holder for this preprint (which was not certified by peer review) is the author/funder, who has granted bioRxiv a license to display the preprint in perpetuity. It is made available under aCC-BY-ND 4.0 International license.

HOIL-1 as being essential for RIG-I signalling and for the IFN-response to virus infections, but SHARPIN as dispensable for this process.

\section{HOIP E3 ligase activity is partially required for RIG-I dependent IFN production}

To further understand the function of LUBAC in RIG-I signalling, we asked whether the E3 ligase activity of HOIP contributes to RIG-I signalling. We used HOIP KO cells with a tandemaffinity purification (TAP)-tagged HOIP or the single point mutant TAP-HOIP-C885S lacking E3 ligase activity ${ }^{27}$. TAP-HOIP and TAP-HOIP-C885S were expressed at similar amounts but at a higher level than endogenous HOIP in WT A549 cells (Fig. 6A). SeV infection of WT, HOIP KO, TAP-HOIP-WT and TAP-HOIP-C885S rescue showed that TAP-HOIP-WT fully rescued the IFN-I/III response to SeV infection and inactivation of HOIP's E3 ligase activity resulted in significantly less IFNB, IFNL and CXCL10 transcription and CXCL10 secretion, when compared with WT A549 cells or HOIP KO cells rescued with WT TAP-HOIP (Fig. 6B, D). There was no observable difference in SeV-driven TBK1, IRF3 or IKB $\alpha$ activation between cells expressing TAP-HOIP or TAP-HOIP-C885S (Fig. 6C), indicating that HOIP'S E3 ligase activity is not required for RIG-I signalling activation. In response to synthetic RNA transfection, TAP-HOIP rescued cells transcribed significantly more IFNB and CXCL10 than TAP-HOIP-C885S cells, confirming the phenotype shown during SeV infection (Fig. 6E). This data indicates that HOIP has a dual role in regulation of RIG-I signalling, being both dependent and independent of the E3 ligase function.

\section{NEMO and TBK1/IKKE are essential for IFN-I responses to RIG-I stimulation}

To further probe the mechanisms downstream of RIG-I that may co-ordinate with LUBAC to activate IFN responses and to assess tools for analysing RIG-I signalling complexes we analysed further A549 KO lines. As expected, MAVS KO cells were unable to mount a transcriptional response to SeV infection, confirming that MAVS is essential for RIG-I signalling in A549 cells $^{6}$ (Supplementary Fig S4A, B). Using NEMO KO cells ${ }^{28}$, we also found that NEMO is essential for the IFN-response triggered by RIG-I signalling ${ }^{29}$, as NEMO KO cells infected with SeV or transfected with RNAs failed to transcribe IFNB, IFNL, or CXCL10, but this response could be fully rescued by re-expression of TAP-NEMO in the KO cells (Fig. 7A, Supplementary Fig. S4C,D). In NEMO KO cells we observed residual NFKBIA transcription, indicating that NEMO contributes to, but is non-essential for RIG-I-driven NF-KB activation 
bioRxiv preprint doi: $h$ ttps://doi.org/10.1101/2022.02.24.481814; this version posted February 24, 2022. The copyright holder for this preprint (which was not certified by peer review) is the author/funder, who has granted bioRxiv a license to display the preprint in perpetuity. It is made available under aCC-BY-ND 4.0 International license.

(Fig. 7A). Downstream of PRRs, the kinases TBK1 and IKKE are necessary for IRF3 signalling ${ }^{9}$. We analysed the potential redundancy of these kinases and their contribution to IRF3 and NF-KB activation following RIG-I stimulation. Individual KO of TBK1 or IKK $\varepsilon^{28}$ had only minor impacts on gene activation following SeV infection or synthetic RNA transfection (Fig 7B and Supplementary Fig. S4E-G). Knockout of both TBK1 and $\mathrm{IKK} \varepsilon$, however, resulted in abrogation of IFN- and IRF3-dependent gene transcription, although had no impact on NFKBIA transcription, indicating that TBK1 and IKKE contribute redundantly to IRF3 activation and are not required for NF-KB activity downstream of RIG-I signalling (Fig. 7B). To confirm these observations, we analysed activation of TBK1, IRF3 and IKB $\alpha$ activation in NEMO, TBK1, IKKE and TBK1/ IKKE KO A549 cells (Fig. 7C). In NEMO KO cells, IRF3 and TBK1 phosphorylation were nearly abrogated following $\mathrm{SeV}$ infection and, although $1 \mathrm{~KB} \alpha$ phosphorylation was maintained, the protein was not degraded in NEMO KO cells (Fig. 7C), consistent with the partial defect in NF-KB-dependent transcription (Fig. 7A). NEMO therefore functions as an essential regulator of RIG-I-driven IRF3 activation and is partially required for IKB $\alpha$ activity. Similarly, IRF3 phosphorylation following $\mathrm{SeV}$ infection was maintained in TBK1 and IKKe single KO cell lines, but in the TBK1/IKKE KO cells, IRF3 phosphorylation was abrogated (Fig. 7D) whilst IKB $\alpha$ phosphorylation and degradation was unaffected (Fig. 7D). Therefore, TBK1 and IKKE act redundantly downstream of RIG-I to phosphorylate IRF3 and activate IFN-I/III transcription but are not required for RIG-I driven NF-KB activation.

\section{LUBAC interacts with TBK1 and NEMO downstream of RIG-I}

Since the E3 ligase activity of HOIP is only partially required for LUBACs function in RIG-I signalling, we explored the possibility that LUBAC plays a structural role in the RIG-I signalling complex. Isolation of the endogenous RIG-I/MAVS signalling complex is complicated by low levels of RIG-I protein expression and its localisation at the mitochondria. We therefore used the TAP-NEMO and TAP-HOIP rescue cell lines to immunoprecipitate protein complexes following $\mathrm{SeV}$ infection. At 3 hours post $\mathrm{SeV}$ infection, HOIP, SHARPIN and TBK1 could all be found in complex with immunoprecipitated NEMO, enriched compared to mock-infected cells (Fig. 7E). By 6 hours post infection, only TBK1 remained in complex with NEMO (Fig. 7E). Similarly, HOIP was found to co- 
bioRxiv preprint doi: https://doi.org/10.1101/2022.02.24.481814; this version posted February 24, 2022. The copyright holder for this preprint (which was not certified by peer review) is the author/funder, who has granted bioRxiv a license to display the preprint in perpetuity. It is made available under aCC-BY-ND 4.0 International license.

immunoprecipitate with TBK1 in an SeV-dependent manner (Fig. 7F). As such, LUBAC is specifically and transiently recruited to NEMO and TBK1 in an SeV-infection-dependent manner, consistent with the requirement for HOIP protein and E3 ligase activity in RIG-I signalling. Overall these results define HOIP and HOIL-1 as critical components of the RIG-I signalling complex required for anti-viral innate immunity.

\section{Discussion}

During RNA virus infection RIG-I is activated by viral RNAs and undergoes a conformational switch allowing the construction of a large, multiprotein signalling complex, which relies on post translational modification of component proteins. Multiple E3 ubiquitin ligases and kinases regulate this dynamic process to generate optimal signalling outputs in a given cellular context. The M1 ubiquitin E3 ligase LUBAC modulates signalling outputs of multiple immune SCs, amplifying gene activation and regulating programmed cell death signalling outputs $^{13}$. During TNFR1 signalling, LUBAC is recruited by binding to the K63-linked ubiquitin chains produced by cIAP1/2. LUBAC then adds M1-linked ubiquitin chains to RIP1, NEMO, TNFR1 and TRADD ${ }^{14,30,31}$, as well as to pre-established K63-linked chains, generating K63/M1-linked heterotypic chains ${ }^{32,33}$. This results in the formation of the TNFR1-SC, also known as complex I of TNFR1 signalling and increased recruitment of NEMO ${ }^{34}$. LUBAC functions similarly in other immune signalling pathways, conjugating linear ubiquitin chains to other targets including RIPK2, TRADD, TNFR1 itself, IRAK1/2/4 and MyD88 ${ }^{35}$. LUBAC E3 ligase activity can also generate M1-/K63-linked heterotypic chains, conjugated to NEMO in IL-1 $\beta$ and TLR3 signalling, RIPK1 in TLR3 signalling, and RIPK2 in NOD2 signalling ${ }^{15,32,33,36}$.

Here we define specific and separate contributions of LUBAC components and M1 chains to RIG-I signalling using a knockout approach in a system where the transcriptional response to intracellular RNAs or infection with $\mathrm{SeV}$ and ZIKV was entirely dependent on RIG-I signalling, as previously reported ${ }^{37-39}$. This approach allowed us to determine specific RIG-I signalling outputs and the relative contributions of LUBAC components to those processes. We identified HOIP and HOIL-1 as essential components of RIG-I signalling that are required for IRF3 and NF-KB activation by RIG-I, and for the IFN-I and III response to dsRNA, ZIKV and $\mathrm{SeV}$. The E3 ligase activity of HOIP is partially required RIG-I signalling, while SHARPIN is dispensable for RIG-I-driven gene activation and may negatively regulate this process in 
bioRxiv preprint doi: https://doi.org/10.1101/2022.02.24.481814; this version posted February 24, 2022. The copyright holder for this preprint (which was not certified by peer review) is the author/funder, who has granted bioRxiv a license to display the preprint in perpetuity. It is made available under aCC-BY-ND 4.0 International license.

human cells. The ligase-independent function of HOIP in RIG-I signalling suggests potential for a contribution of HOIP as a scaffold or for the ligase function of HOIL-1 in activating downstream signalling. We also confirmed the essential contribution of MAVS, NEMO and TBK1/IKKE to RIG-I signalling and show that LUBAC is recruited to NEMO during SeV infection, in keeping with the requirement of HOIP and HOIL-1 for signalling activation downstream of NEMO.

Other descriptions of LUBAC in RIG-I signalling have analysed RIG-I signalling outputs in human cells overexpressing LUBAC, using siRNA knockdowns of HOIP and HOIL-1, or in murine cells expressing an incomplete HOIL-1 deletion, leading to inconsistent conclusions depending on the system $7,16,17,19,20$. Incomplete reduction or partial genetic deletion of LUBAC components may not result in the same outcome as complete deletion of the protein, and overexpression of LUBAC is known to provide conflicting positive and negative signals. Our data using cells in which HOIP or HOIL-1 are fully genetically ablated clarify the role of these proteins in RIG-I driven IRF3 and NF-kB activation and are similar to what we observed in TLR3 signalling ${ }^{15}$. Previous studies using cells from the SHARPIN mutant $c p d m$ mouse infected with vesicular stomatitis virus concluded that LUBAC does not regulate RNA virus infection, are now clarified by our data showing that SHARPIN is not required for RIG-I signalling, even when the other components are ${ }^{16}$. Our data are more consistent with that of Brazee et al. showing a reduced IFN response in influenza A virus-infected mice lacking HOIP or HOIL-1 in the lung epithelium ${ }^{19}$. The differential requirement for LUBAC components has been observed in other contexts, such in thymic development ${ }^{40}$, and the E3 ligase-independent functions of HOIP are also observed in B cell receptor signalling ${ }^{41}$. It will be interesting to understand further how SHARPIN regulates NF-kB activation in the context of multiple receptor SCs but is not required for RIG-I-driven NF-KB activation.

We propose a two-step model for how LUBAC regulates RIG-I signalling, in which HOIP and HOIL-1 act as scaffolds to allow proper formation of the RIG-I signalling complex, before HOIP conjugates linear ubiquitin chains within the complex to enhance and stabilise recruitment of downstream signalling proteins. We suggest that LUBAC is recruited to the RIG-I signalling complex by binding K63-ubiquitin chains, upon which it recruits/activates TBK1 and conjugates M1 chains to NEMO or (an)other target(s), further enhancing 
bioRxiv preprint doi: https://doi.org/10.1101/2022.02.24.481814; this version posted February 24, 2022. The copyright holder for this preprint (which was not certified by peer review) is the author/funder, who has granted bioRxiv a license to display the preprint in perpetuity. It is made available under aCC-BY-ND 4.0 International license.

recruitment of NEMO, LUBAC and other M1-binding proteins, thereby amplifying downstream signalling. M1-ubiquitin chains do not appear to be required for the role of LUBAC in regulating either TBK1 or IRF3 activation, or the phosphorylation and degradation of $I_{K B} \alpha$ to activate NF-KB, so this is only dependent on the presence of HOIP and HOIL-1 at the RIG-I-SC and not M1-ubiquitin chain formation. M1 ubiquitin chains are, however, required to enhance recruitment of signalling proteins and boost downstream responses. We suggest that this may be caused by the formation of $\mathrm{M} 1 / \mathrm{K} 63$-linked hybrid ubiquitin chains that function to amplify IRF3 activation in the RIG-I-SC. The mechanism by which this regulation occurs also relies on our knowledge of LUBAC at the TNFR1-SC. In TNFR1 signalling, both NEMO and LUBAC are initially recruited by binding to ubiquitin chains generated by clAPs $^{14,42}$. LUBAC then adds M1 ubiquitin chains to various components of the TNFR1-SC ${ }^{14,30,31,43}$, including TRADD and RIP1, which enhances recruitment and retention of NEMO, which a much higher affinity for M1-ubiquitin chains than K63/K11-linked chains $^{30,34,44}$. The recruitment of TBK1 and IKKE to the TNFR1-SC is also mediated largely by M1 ubiquitin chains, as well as TANK and NAP1 $1^{31,45}$. Similarly, TRAF proteins have been shown to produce K63-ubiquitin chains that recruit NEMO to the RIG-I signalling complex. Therefore, we propose that K63-ubiquitin chains generated by TRAFs recruit LUBAC and NEMO to the RIG-I signalling complex, and that the presence of both LUBAC and NEMO here enables recruitment and activation of TBK1/IKK $\varepsilon$ and IRF3, as well as NF-KB. Overall our data adds detail to the significant contribution of LUBAC to anti-viral immunity and places HOIP and HOIL-1, but not SHARPIN, as key regulators of the IFN response to infection by RNA viruses.

\section{Acknowledgements}

This work was funded by a Wellcome Trust PhD studentship 203778/Z/16/Z to HCT and BF, a UKRI/BBSRC research project grant BB/S001336/1 to BF, Conselho Nacional de Desenvolvimento Científico e Tecnológico (CNPq) grants 307889/2020-3 and 407609/2018-0 to DSM, a Cancer Research UK Programme Grant (A17341), a Wellcome Trust Investigator Award (214342/Z/18/Z), a Medical Research Council Grant (MR/S00811X/1), two collaborative research centre grants (CRC 1399, C06, and SFB1403-414786233) funded by the Deutsche Forschungsgemeinschaft (DFG) and an Alexander von Humboldt Foundation Professorship awarded to HW. 


\section{Conflict of interest}

The authors declare no conflict of interest.

\section{Data availability}

The datasets used during the current study are available from the corresponding author on reasonable request. All data generated or analysed during this study are included in this published article and its supplementary information files.

\section{Author Contributions}

BJF, HT, HW, NI and DM performed study concept and design; HT, BJF, HW, ER, DM, NI and DM performed development of methodology and writing, review and revision of the paper; $H T, C L, E R, D M, D P, M O$, and BJF provided acquisition, analysis and interpretation of data, and statistical analysis; All authors read and approved the final paper.

\section{References}

1. McNab, F., Mayer-Barber, K., Sher, A., Wack, A. \& O'Garra, A. Type I interferons in infectious disease. Nat. Rev. Immunol. 2015152 15, 87-103 (2015).

2. Rehwinkel, J. et al. RIG-I detects viral genomic RNA during negative-strand RNA virus infection. Cell 140, 397-408 (2010).

3. Yoneyama, M. et al. The RNA helicase RIG-I has an essential function in doublestranded RNA-induced innate antiviral responses. Nat. Immunol. 5, 730-7 (2004).

4. Hou, F. et al. MAVS forms functional prion-like aggregates to activate and propagate antiviral innate immune response. Cell 146, 448-61 (2011).

5. Reikine, S., Nguyen, J. B. \& Modis, Y. Pattern Recognition and Signaling Mechanisms of RIG-I and MDA5. Front. Immunol. 342 (2014).

6. Goubau, D., Deddouche, S. \& Reis e Sousa, C. Cytosolic sensing of viruses. Immunity 38, 855-69 (2013).

7. Liu, S. et al. MAVS recruits multiple ubiquitin E3 ligases to activate antiviral signaling cascades. Elife 2, e00785 (2013).

8. Liu, S. et al. Phosphorylation of innate immune adaptor proteins MAVS, STING, and 
bioRxiv preprint doi: https://doi org/10.1101/2022.02.24.481814 this version posted February 24, 2022. The copyright holder for this

TRIF induces IRF3 activation. Science (80-. ). 347, (2015).

9. $\quad$ Fitzgerald, K. A. et al. IKKE and TBK1 are essential components of the IRF3 signaling pathway. Nat. Immunol. 4, 491-496 (2003).

10. Kim, T. K. \& Maniatis, T. The mechanism of transcriptional synergy of an in vitro assembled interferon- $\beta$ enhanceosome. Mol. Cell 1, 119-129 (1997).

11. Fang, R. et al. MAVS activates TBK1 and IKKE through TRAFs in NEMO dependent and independent manner. PLOS Pathog. 13, e1006720 (2017).

12. Shimizu, Y., Taraborrelli, L. \& Walczak, H. Linear ubiquitination in immunity. Immunol. Rev. 266, 190-207 (2015).

13. Walczak, H., Iwai, K. \& Dikic, I. Generation and physiological roles of linear ubiquitin chains. BMC Biol. 10, 23 (2012).

14. Haas, T. L. et al. Recruitment of the Linear Ubiquitin Chain Assembly Complex Stabilizes the TNF-R1 Signaling Complex and??Is Required for TNF-Mediated Gene Induction. Mol. Cell 36, 831-844 (2009).

15. Zinngrebe, J. et al. LUBAC deficiency perturbs TLR3 signaling to cause immunodeficiency and autoinflammation. J. Exp. Med. 213, (2016).

16. Belgnaoui, S. M. et al. Linear ubiquitination of NEMO negatively regulates the interferon antiviral response through disruption of the MAVS-TRAF3 complex. Cell Host Microbe 12, 211-22 (2012).

17. Inn, K. S. et al. Linear Ubiquitin Assembly Complex Negatively Regulates RIG-I- and TRIM25-Mediated Type I Interferon Induction. Mol. Cell 41, 354-365 (2011).

18. Zhang, M. et al. Negative feedback regulation of cellular antiviral signaling by RBCK1mediated degradation of IRF3. Cell Res. 20081811 18, 1096-1104 (2008).

19. Brazee, P. L. et al. Linear ubiquitin assembly complex regulates lung epithelial-driven responses during influenza infection. J. Clin. Invest. 130, 1301-1314 (2020).

20. MacDuff, D. A. et al. HOIL1 Is Essential for the Induction of Type I and III Interferons by MDA5 and Regulates Persistent Murine Norovirus Infection. J. Virol. 92, 13681386 (2018).

21. Nakaya, T. et al. Gene induction pathways mediated by distinct IRFs during viral infection. Biochem. Biophys. Res. Commun. 283, 1150-1156 (2001).

22. Ito, C. Y., Kazantsev, A. G., Baldwin, A. S. \& Jr. Three NF-kappa B sites in the I kappa Balpha promoter are required for induction of gene expression by TNF alpha. Nucleic 
Acids Res. 22, 3787 (1994).

23. Chattopadhyay, S et al. Ubiquitination of the Transcription Factor IRF-3 Activates RIPA, the Apoptotic Pathway that Protects Mice from Viral Pathogenesis. Immunity 44, 1151-1161 (2016).

24. Schock, S. N. et al. Induction of necroptotic cell death by viral activation of the RIG-I or STING pathway. Cell Death Differ. 24, 615-625 (2017).

25. Peltzer, N. et al. HOIP deficiency causes embryonic lethality by aberrant TNFR1mediated endothelial cell death. Cell Rep. 9, 153-165 (2014).

26. Ikeda, F. et al. SHARPIN forms a linear ubiquitin ligase complex regulating NF-KB activity and apoptosis. Nature 471, 637 (2011).

27. Peltzer, N. et al. LUBAC is essential for embryogenesis by preventing cell death and enabling haematopoiesis. Nature 557, 112-117 (2018).

28. Lafont, E. et al. TBK1 and IKKE prevent TNF-induced cell death by RIPK1 phosphorylation. Nat. Cell Biol. 20, 1389-1399 (2018).

29. Zhao, T. et al. The NEMO adaptor bridges the nuclear factor-KB and interferon regulatory factor signaling pathways. Nat. Immunol. 8, 592-600 (2007).

30. Tokunaga, F. et al. Involvement of linear polyubiquitylation of NEMO in NF-KB activation. Nat. Cell Biol. 2009112 11, 123-132 (2009).

31. Draber, P. et al. LUBAC-Recruited CYLD and A20 Regulate Gene Activation and Cell Death by Exerting Opposing Effects on Linear Ubiquitin in Signaling Complexes. Cell Rep. 13, 2258-2272 (2015).

32. Emmerich, C.H. et al. Lys63/Met1-hybrid ubiquitin chains are commonly formed during the activation of innate immune signalling. Biochem. Biophys. Res. Commun. 474, 452-461 (2016).

33. Emmerich, C. H. et al. Activation of the canonical IKK complex by K63/M1-linked hybrid ubiquitin chains. Proc. Natl. Acad. Sci. U. S. A. 110, 15247-15252 (2013).

34. Rahighi, S. et al. Specific Recognition of Linear Ubiquitin Chains by NEMO Is Important for NF-KB Activation. Cell 136, 1098-1109 (2009).

35. Dittmar, G. \& Winklhofer, K. F. Linear Ubiquitin Chains: Cellular Functions and Strategies for Detection and Quantification. Front. Chem. 7, 915 (2019).

36. Damgaard, R. B. et al. The Ubiquitin Ligase XIAP Recruits LUBAC for NOD2 Signaling in Inflammation and Innate Immunity. Mol. Cell 46, 746-758 (2012). 
37. Baum, A., Sachidanandam, R. \& García-Sastre, A. Preference of RIG-I for short viral RNA molecules in infected cells revealed by next-generation sequencing. Proc. Natl. Acad. Sci. U. S. A. 107, 16303-16308 (2010).

38. Chazal, M. et al. RIG-I Recognizes the 5' Region of Dengue and Zika Virus Genomes. Cell Rep. 24, 320-328 (2018).

39. Hertzog, J. et al. Infection with a Brazilian isolate of Zika virus generates RIG-I stimulatory RNA and the viral NS5 protein blocks type I IFN induction and signaling. Eur. J. Immunol. 48, 1120-1136 (2018).

40. Jain, R. et al. Dual roles for LUBAC signaling in thymic epithelial cell development and survival. Cell Death Differ. 28, 2946-2956 (2021).

41. Dubois, S. M. et al. A catalytic-independent role for the LUBAC in NF-KB activation upon antigen receptor engagement and in lymphoma cells. Blood 123, 2199-2203 (2014).

42. Gyrd-Hansen, M. \& Meier, P. IAPs: from caspase inhibitors to modulators of NFkappaB, inflammation and cancer. Nat. Rev. Cancer 10, 561-574 (2010).

43. Gerlach, B. et al. Linear ubiquitination prevents inflammation and regulates immune signalling. Nature 471, 591-596 (2011).

44. Lo, Y. C. et al. Structural basis for recognition of diubiquitins by NEMO. Mol. Cell 33, 602-615 (2009).

45. Kupka, S., Reichert, M., Draber, P. \& Walczak, H. Formation and removal of polyubiquitin chains in the regulation of tumor necrosis factor-induced gene activation and cell death. FEBS J. 283, 2626-2639 (2016). 
bioRxiv preprint doi: https://doi org/10.1101/2022.02.24.481814 this version posted February 24, 2022. The copyright holder for this preprint (which was not certified by peer review) is the author/funder, who has granted bioRxiv a license to display the preprint in perpetuity. It is made available under aCC-BY-ND 4.0 International license.

\section{Figure Legends}

Figure 1: RIG-I dependent RNA and RNA virus sensing in A549 cells A) Western blotting analysis of A549 WT and RIG-I -/- cells with and without stimulation with IFN $\alpha$ for 24 hours. QPCR to measure transcription of indicated genes in A549 WT and RIG-I -/- cells stimulated by B) SeV infection at 1:300 dilution, C) Zika virus infection at MOI 3, D) transfection with 1 $\mu \mathrm{g} 3 \mathrm{p}-\mathrm{hpRNA}$ and E) transfection with $1 \mu \mathrm{g} \operatorname{Poly}(\mathrm{I}: \mathrm{C})$.

Figure 2: HOIP is required for RIG-I driven transcription, chemokine secretion and signalling pathway activation A549 WT and HOIP -/- infected with SeV at 1:300 dilution and A) qPCR to measure transcription of indicated genes and B) Western blotting analysis in the presence and absence of $10 \mu \mathrm{M}$ MG-132. C) qPCR to measure transcription of indicated genes in A549 WT and HOIP -/- cells transfected with $1 \mu \mathrm{g}$ 3p-hpRNA or Poly(l:C). D) ELISA to measure CXCL10 secretion in A549 WT and HOIP -/- cells infected with SeV at 1:300 dilution or transfected with $1 \mu \mathrm{g} 3 \mathrm{p}$-hpRNA or $1 \mu \mathrm{g}$ Poly(l:C).

Figure 3: HOIP is required for ZIKV-driven interferon responses. A549 WT and HOIP -/- cells infected with ZIKV at MOI 3 and A) qPCR to measure transcription of indicated genes, B) ZIKV replication measured by plaque assay on Vero cells and C) Western blotting analysis. Quantification of nuclear translocation of D) NF-אB P65 and E) IRF3 in A549 WT and HOIP -/cells infected with ZIKV at MOI 1 for 24 hours or stimulated with $100 \mathrm{ng} / \mathrm{mL}$ TNF, analysed by immunofluorescence (left panels) and quantified by scoring cells with nuclear staining (right panels).

Figure 4: HOIL-1 is required for RIG-I immune response to SeV and synthetic RNAs MEF TNF -/- Rbck +/- and TNF -/- Rbck -/- cells infected with SeV at a 1:300 dilution and A) qPCR to measure transcription of indicated genes and B) Western blotting analysis of signalling protein activation in the presence and absence of $10 \mu \mathrm{M}$ MG-132. qPCR to measure transcription of indicated genes in MEF TNF -/- HOIL +/- and TNF -/- HOIL -/- cells transfected with C) $1 \mu \mathrm{g} 3 \mathrm{p}$-hpRNA and D) $1 \mu \mathrm{g}$ Poly(I:C). 
bioRxiv preprint doi: https://doi org/10.1101/2022.02 24.481814 this version posted February 24, 2022. The copyright holder for this preprint (which was not certified by peer review) is the author/funder, who has granted bioRxiv a license to display the preprint in perpetuity. It is made available under aCC-BY-ND 4.0 International license.

Figure 5: SHARPIN is not required for RIG-I immune response to SeV and synthetic RNAs in A549 cells A549 WT and SHARPIN -/- cells infected with SeV at a 1:300 dilution and A) qPCR to measure transcription of indicated genes, B) Western blotting analysis of signalling protein activation in the presence and absence of $10 \mu \mathrm{M}$ MG-132 and C) CXCL10 secretion measured by ELISA. qPCR to measure transcription of indicated genes in A549 WT and SHARPIN cells transfected with D) $1 \mu \mathrm{g} 3 p$-hpRNA and E) $1 \mu \mathrm{g}$ Poly(I:C).

Figure 6: The E3 ligase activity of LUBAC is partially required for its function in RIG-I signalling A) Western blotting analysis of A549 WT, HOIP -/-, TAP-HOIP-WT and TAP-HOIPC885S cells. A549 WT, HOIP -/-, TAP-HOIP-WT and TAP-HOIP-C885S cells infected with SeV at a 1:300 dilution and B) qPCR to measure transcription of indicated genes and C) ELISA to measure CXCL10 secretion. D) Western blotting analysis of signalling protein activation in A549 TAP-HOIP-WT and TAP-HOIP-C885S cells infected with SeV at a 1:300 dilution in the presence and absence of $10 \mu \mathrm{M}$ MG-132. qPCR to measure transcription of indicated genes in A549 WT, HOIP -/-, TAP-HOIP-WT and TAP-HOIP-C885S cells transfected with E) $1 \mu \mathrm{g} 3 \mathrm{p}$ hpRNA and F) $1 \mu \mathrm{g}$ Poly(l:C).

Figure 7: LUBAC interacts with TBK1 and NEMO downstream of RIG-I activation qPCR to measure transcription of indicated genes during SeV infection at 1:300 dilution in A) A549 WT, NEMO -/-, NEMO -/- + TAP-NEMO cells and B) A549 WT, TBK1 -/-, IKKE -/- andTBK1/IKKE -/- cells. Western blotting analysis of signalling protein phosphorylation during SeV infection at 1:300 dilution in A) A549 WT, NEMO -/-, NEMO -/- + TAP-NEMO cells and B) A549 WT, TBK1 -/-, IKKE -/- andTBK1/IKKE -/- cells. Western blotting analysis of Flag-M2 IP in E) A549 TAP-NEMO and F) A549 TAP-HOIP-WT cells infected with SeV at a 1:300 dilution 
Figure 1 perpetuity. It is made available under aCC-BY-ND 4.0 International license.

A

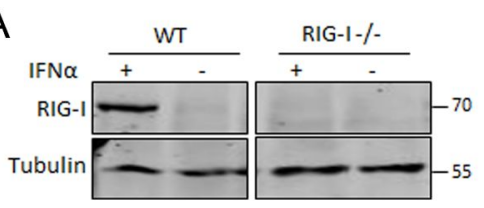

B Sendai virus
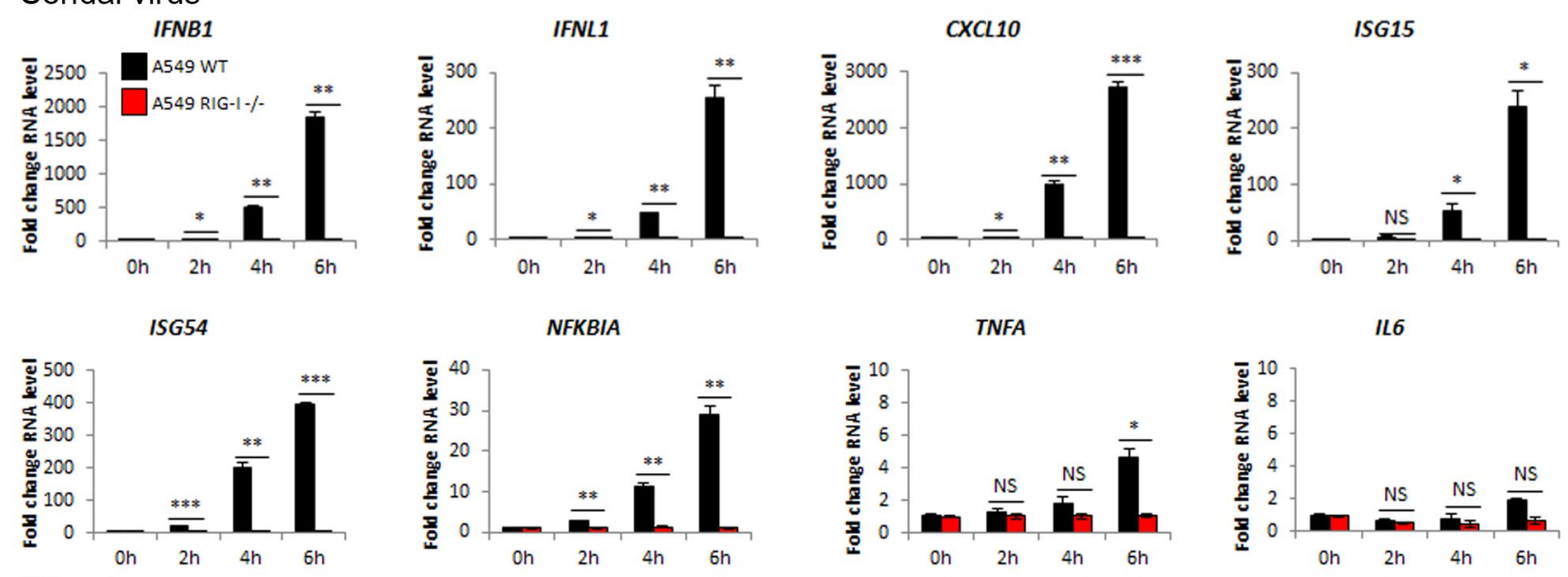

C Zika virus ${ }_{\text {IFNB1 }}$

IFNL1
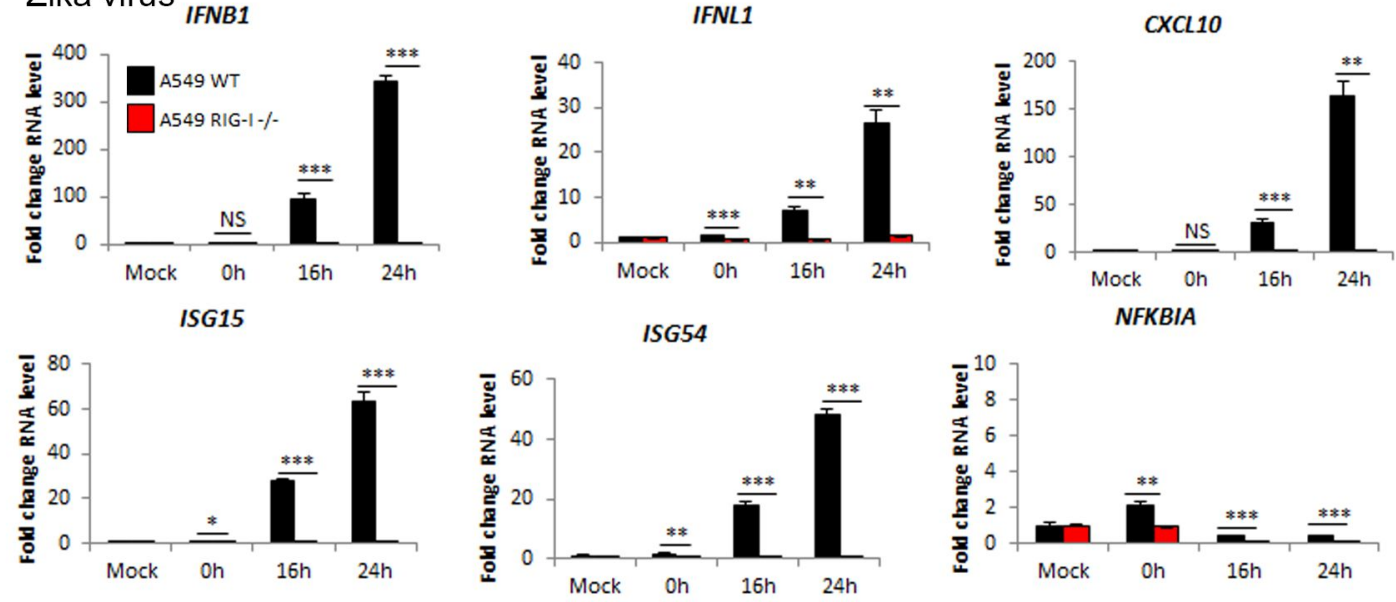

D 3p-hpRNA
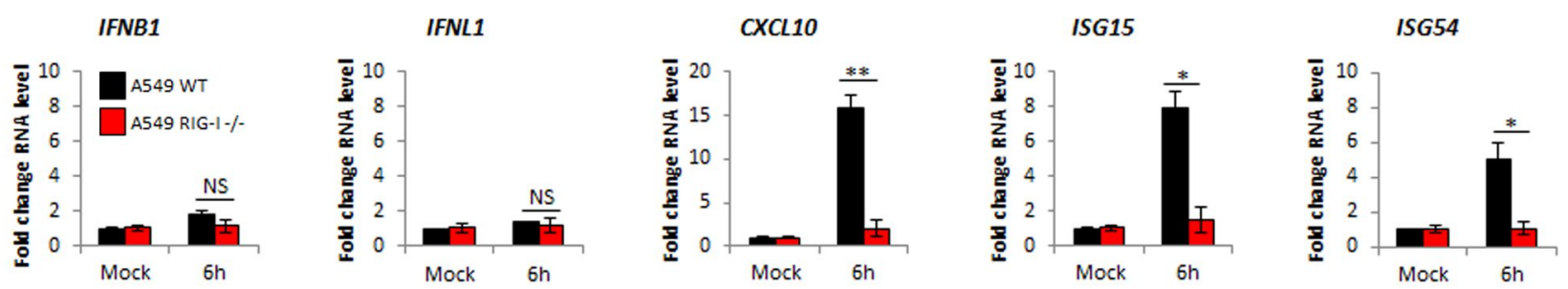

E Poly(I:C)

IFNB1

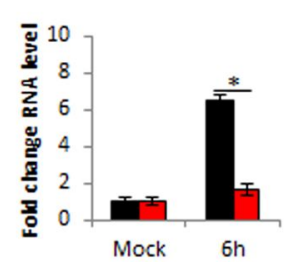

IFNL1

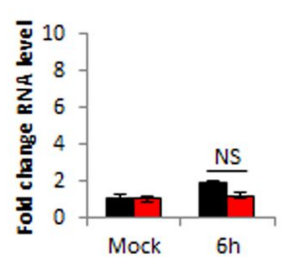

CXCL10

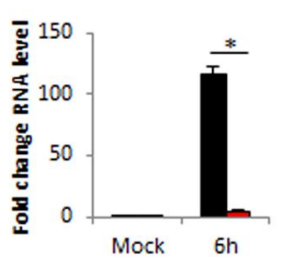

ISG15

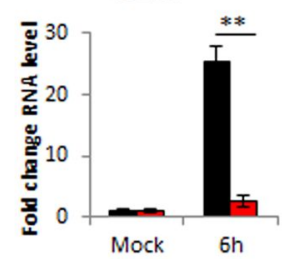

ISG54

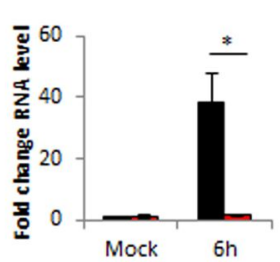


Figure 2 perpetuity. It is made available under aCC-BY-ND 4.0 International license.

A Sendai virus
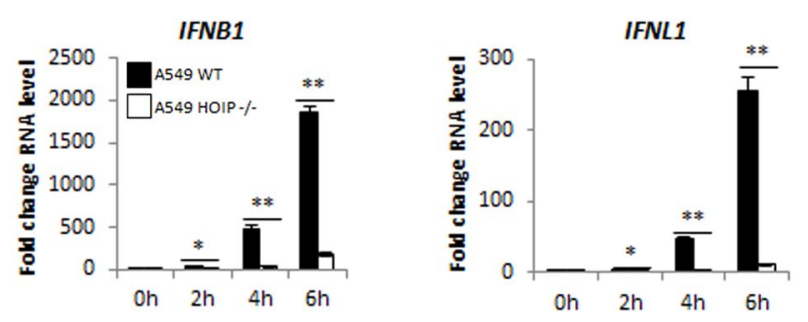

ISG54

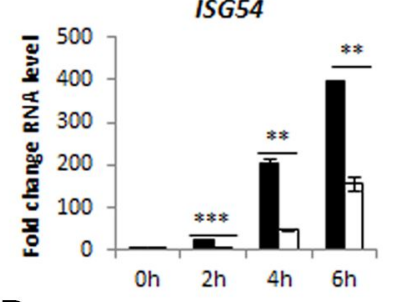

B 3p-hpRNA

\section{IFNB1}

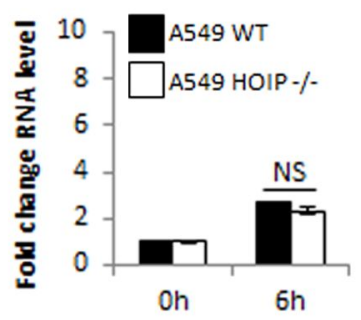

Poly(l:C)

ISG15

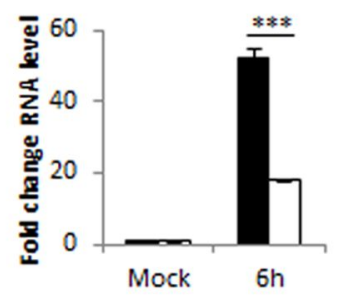

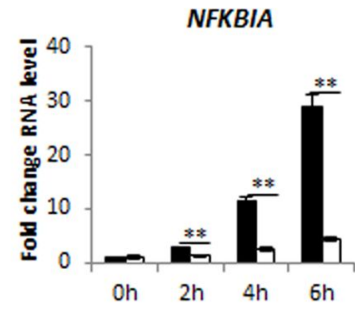

CXCL10

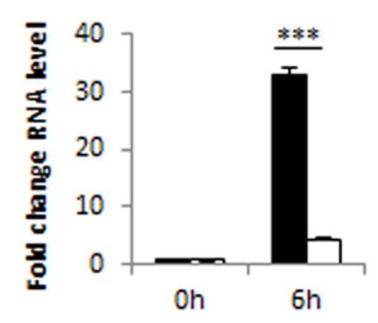

CXCL10

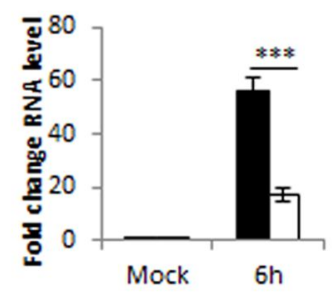

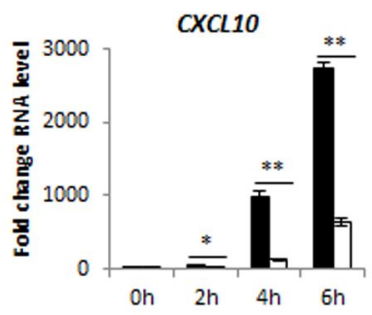

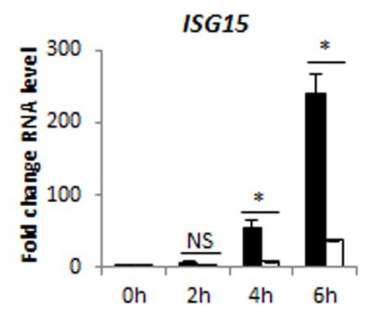

C

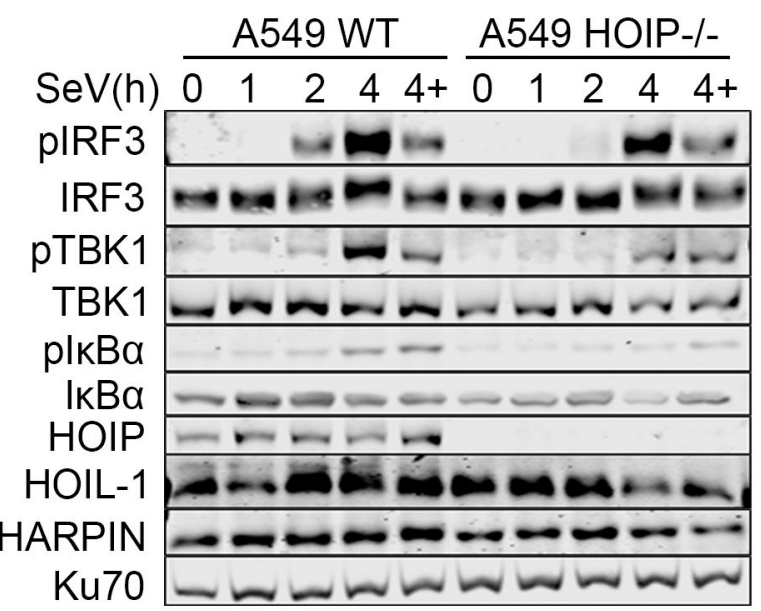

D $\mathrm{SeV}$

3p-hpRNA

Poly(l:C)
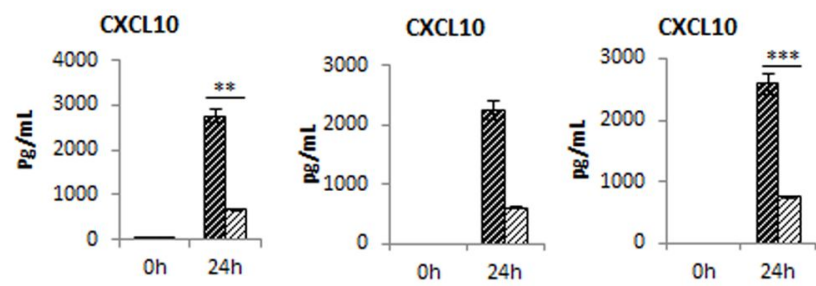
bioRxiv preprint doi: https://doi.org/10.1101/2022.02.24.481814; this version posted February 24, 2022. The copyright holder for this Figure 3 preprint (which was not certified by peer review) is the author/funder, who has granted bioRxiv a license to display the preprint in

A Zika virus

IFNB1

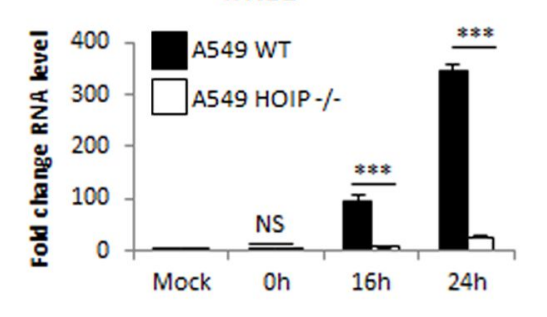

B

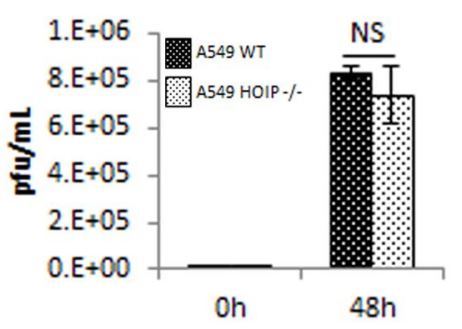

IFNL1

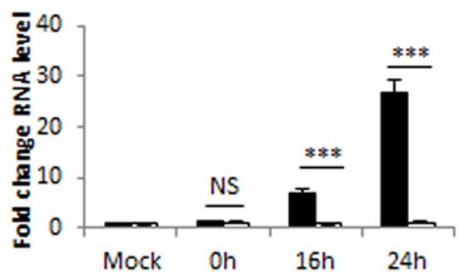

C

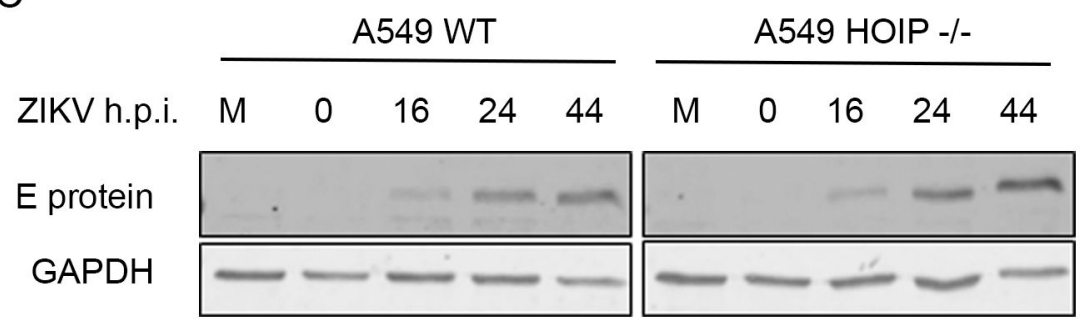

D

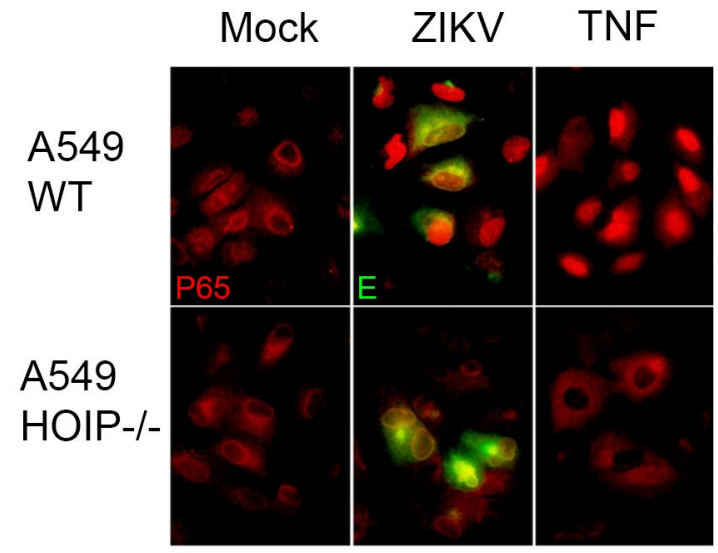

P65 translocation

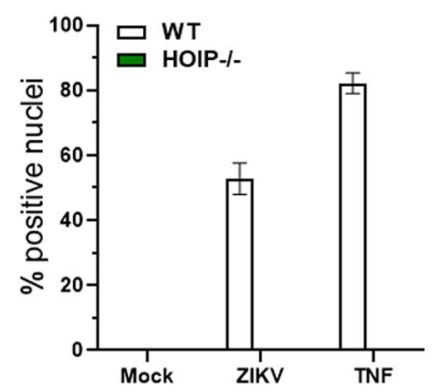

E
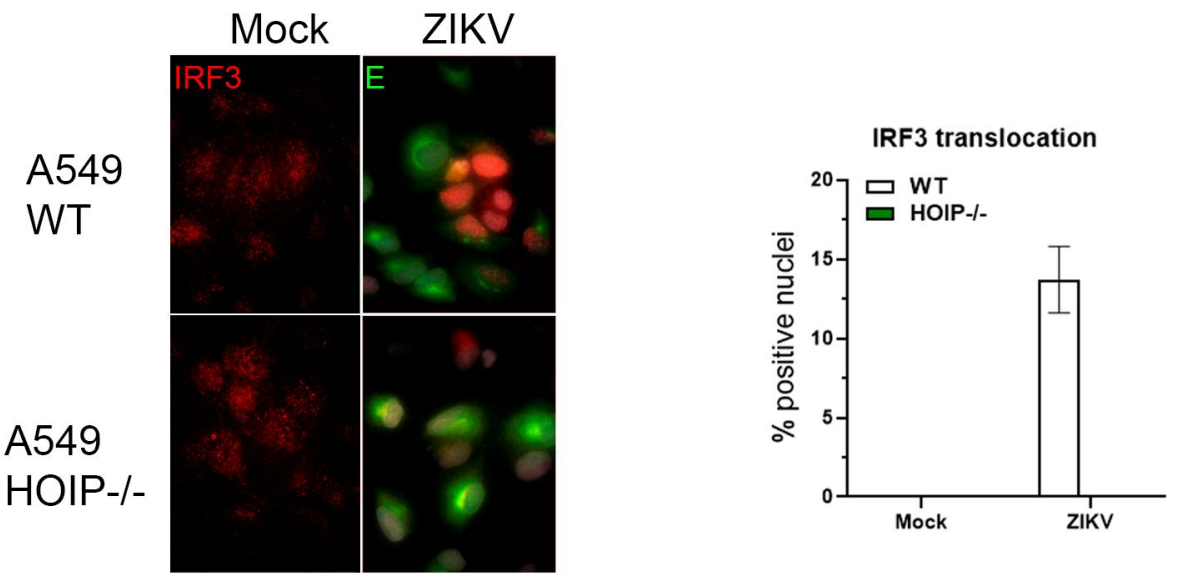
Figure 4

A Senxiv preprint doi: https://doi.org/10.1101/2022.02.24.481814; this version posted February 24, 2022. The copyright holder for this A Senerepipipitulgich was not certified by peer review) is the author/funder, who has granted bioRxiv a license to display the preprint in Ifnb1 perpetuity. It is made available under aCC-BY-ND 4.0 International license.

Isg56

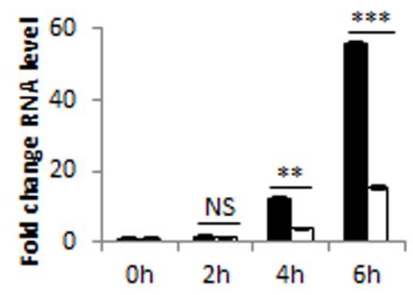

Nfkbia

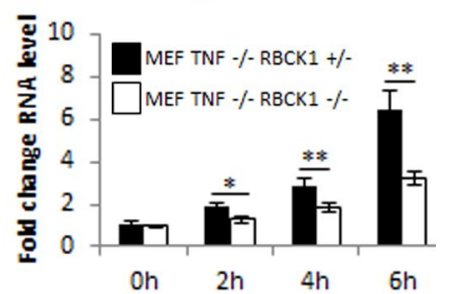

B

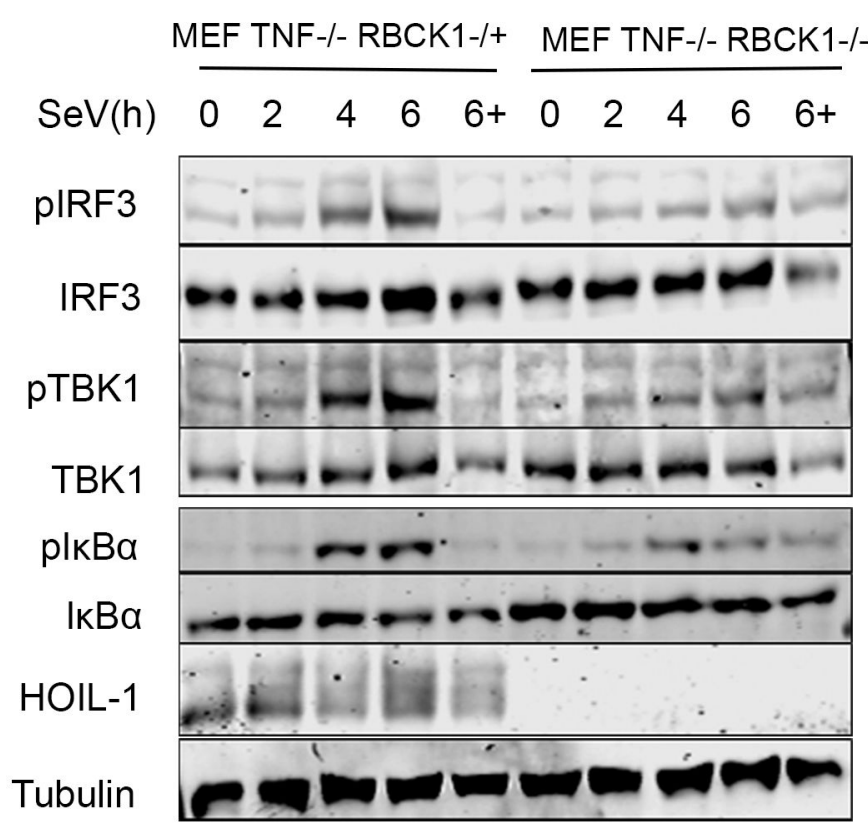

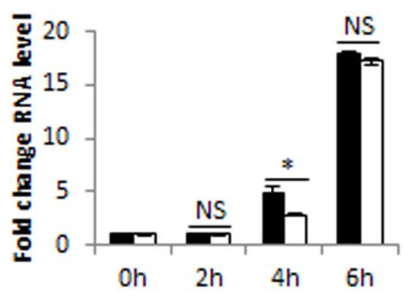

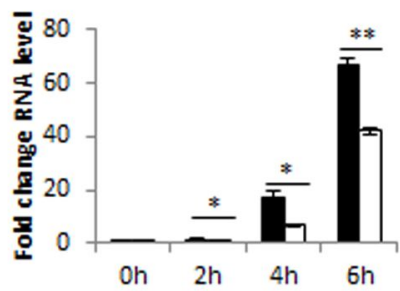

C 3p-hpRNA
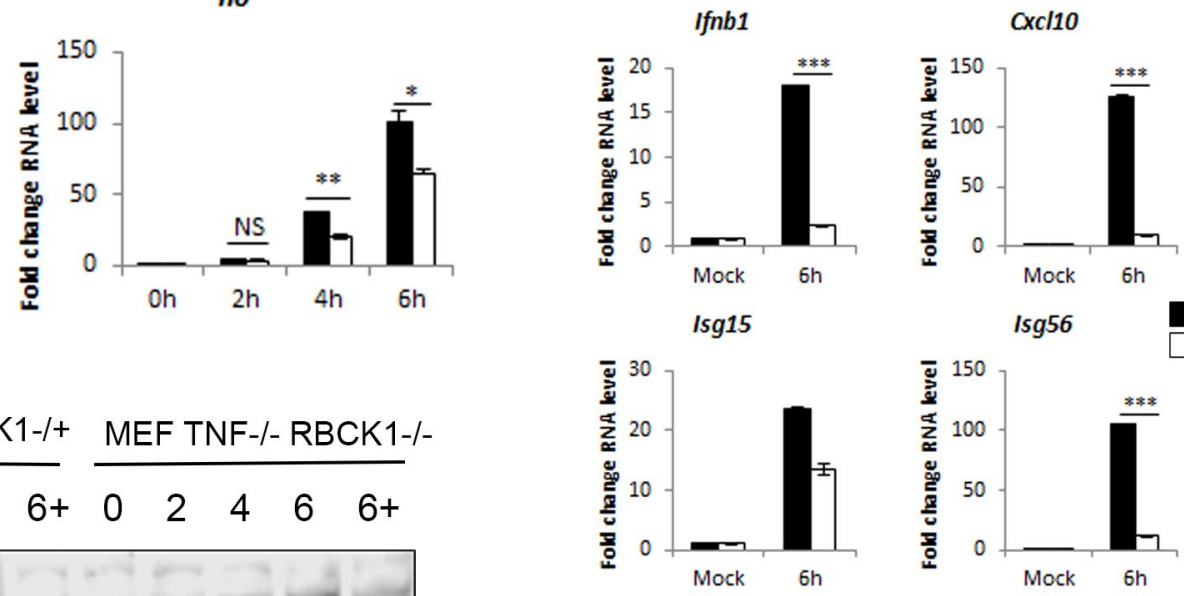

D Poly(l:C)
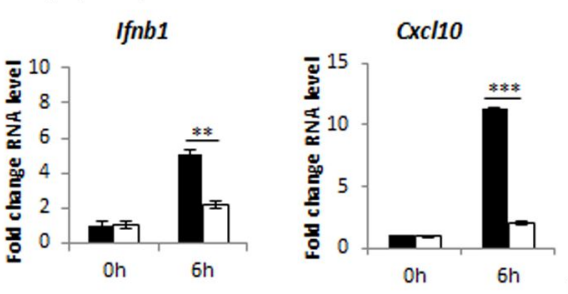

$\operatorname{sg} 15$
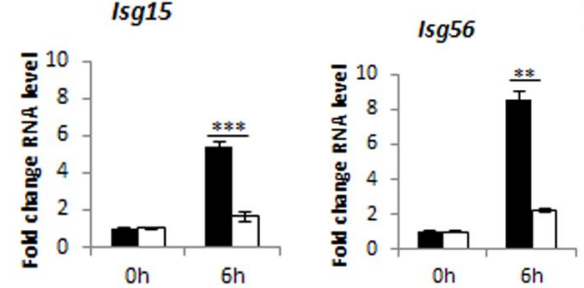
Figure 5

bioRxiv preprint doi: https://doi.org/10.1101/2022.02.24.481814; this version posted February 24, 2022. The copyright holder for this A Sendai virus (which was not certified by peer review) is the author/funder, who has granted bioRxiv a license to display the preprint in
perpetuity. It is made available under aCC-BY-ND 4.0 International license.

IFNB1

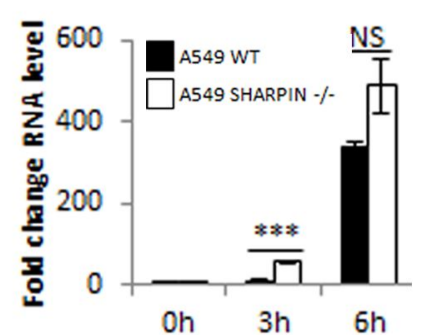

ISG54

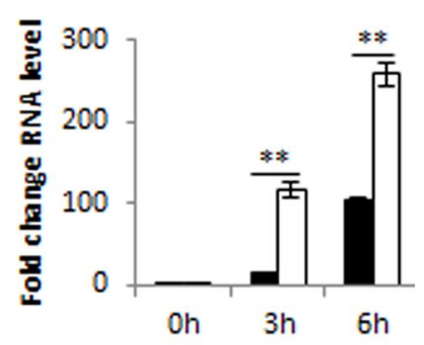

IFNLI

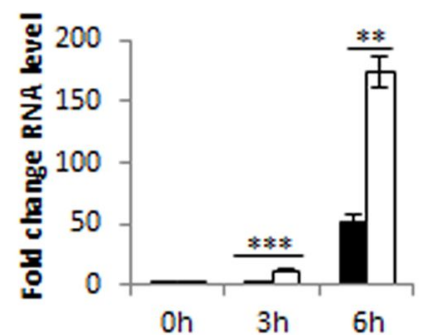

NFKBIA

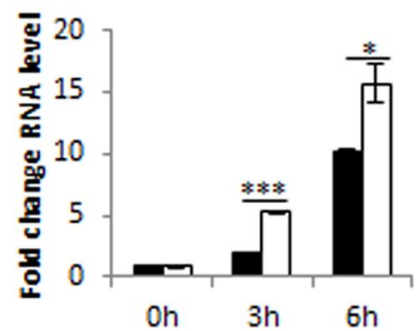

C

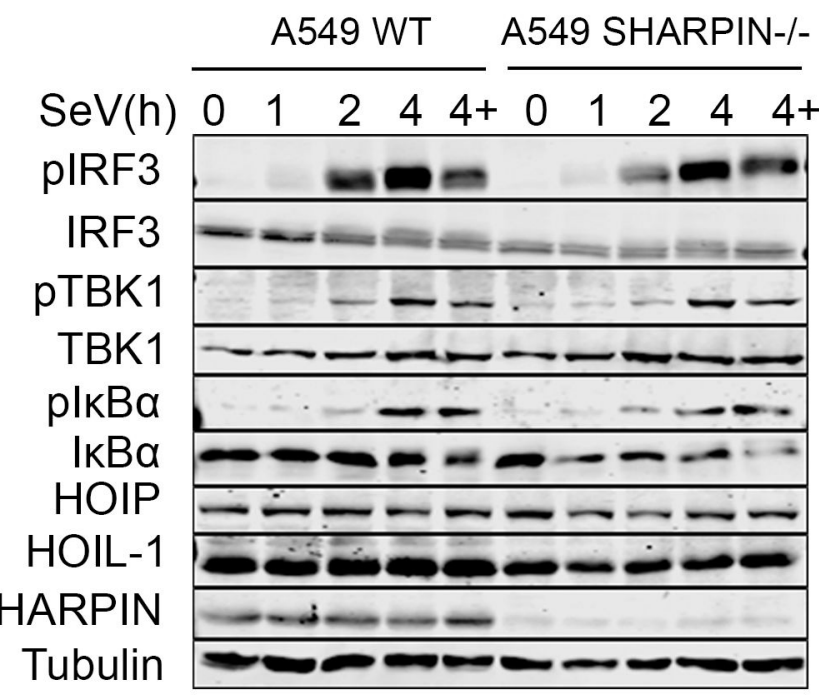

CXCL10

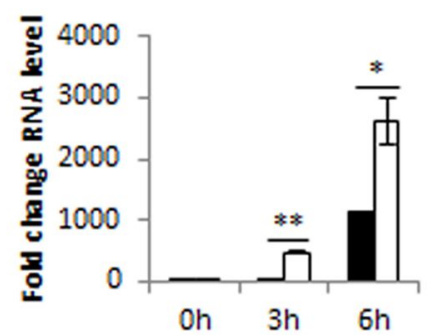

B 3p-hpRNA

CXCL10

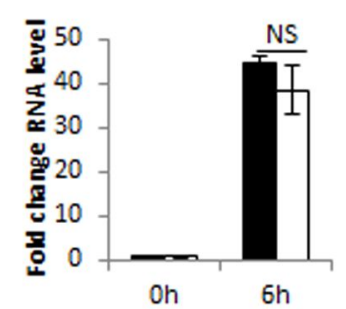

D Sendai virus

\section{CXCL10}

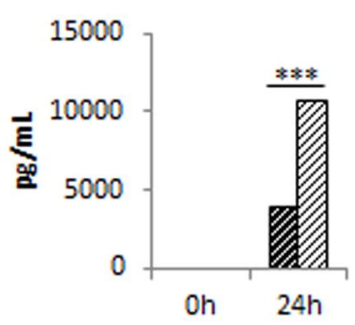

ISG15

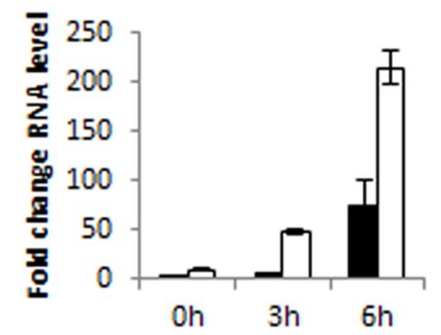

ISG15

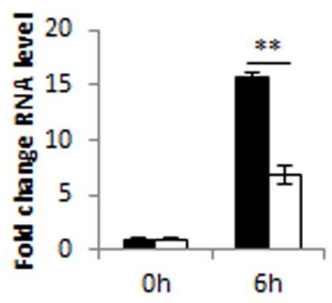

$\mathbb{Z}_{\text {A5 } 49 \text { WT }}$

W549 SHARPIN -1- 
Figureio' xiv preprint doi: https://doi.org/10.1101/2022.02.24.481814; this version posted February 24, 2022. The copyright holder for this A preprint (which was not certified bBpegervida)i isvimej\&uthor/funder, who has granted bioRxiv a license to display the preprint in TAP TAP perpetuity. It is made available under aCC-BY-ND 4 folnternational license.

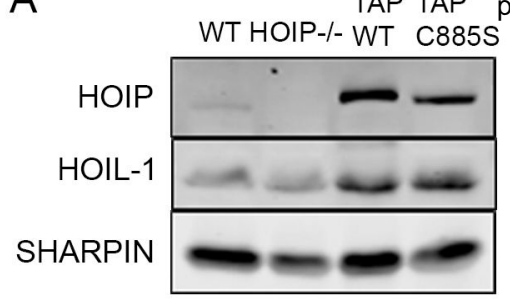

C

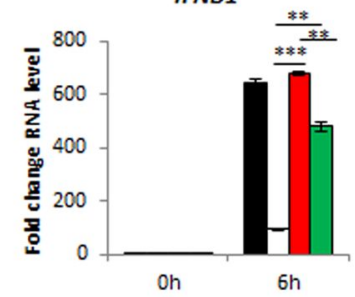

\section{TAP-HOIP-WT TAP-HOIP-C885S}

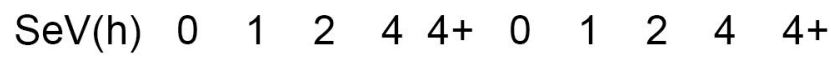
pIRF3

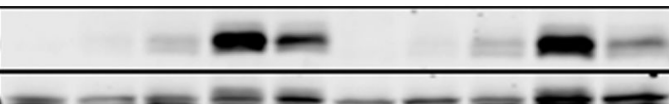

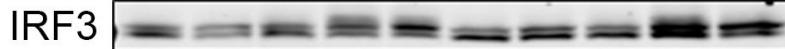
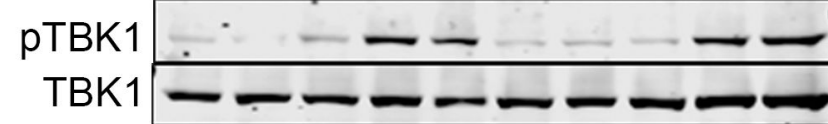

plkBa

$\mathrm{IKBa}$

HOIP

HOIL-1

SHARPIN

Tubulin

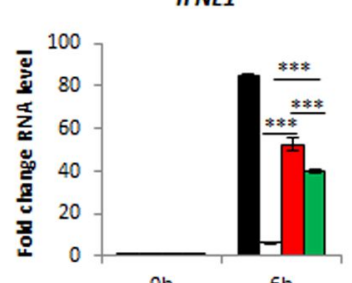

$6 \mathrm{~h}$

$\mathrm{D}$

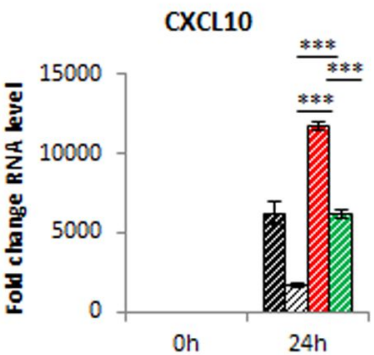

E 3p-hpRNA
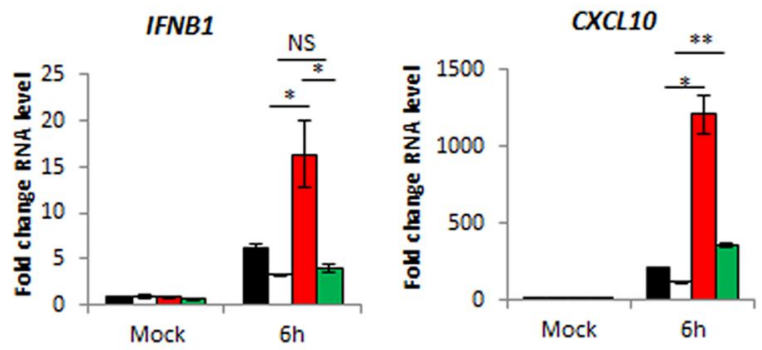
Figurięiv preprint doi: https://doi.org/10.1101/2022.02.24.481814; this version posted February 24, 2022. The copyright holder for this Figur preprint (which was not certified by peer review) is the author/funder, who has granted bioRxiv a license to display the preprint in

A Sendai virus
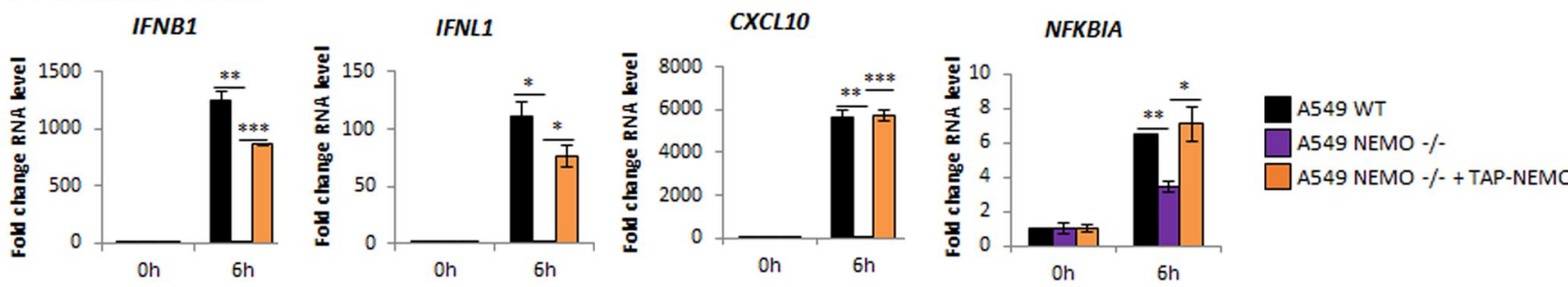

B Sendai virus
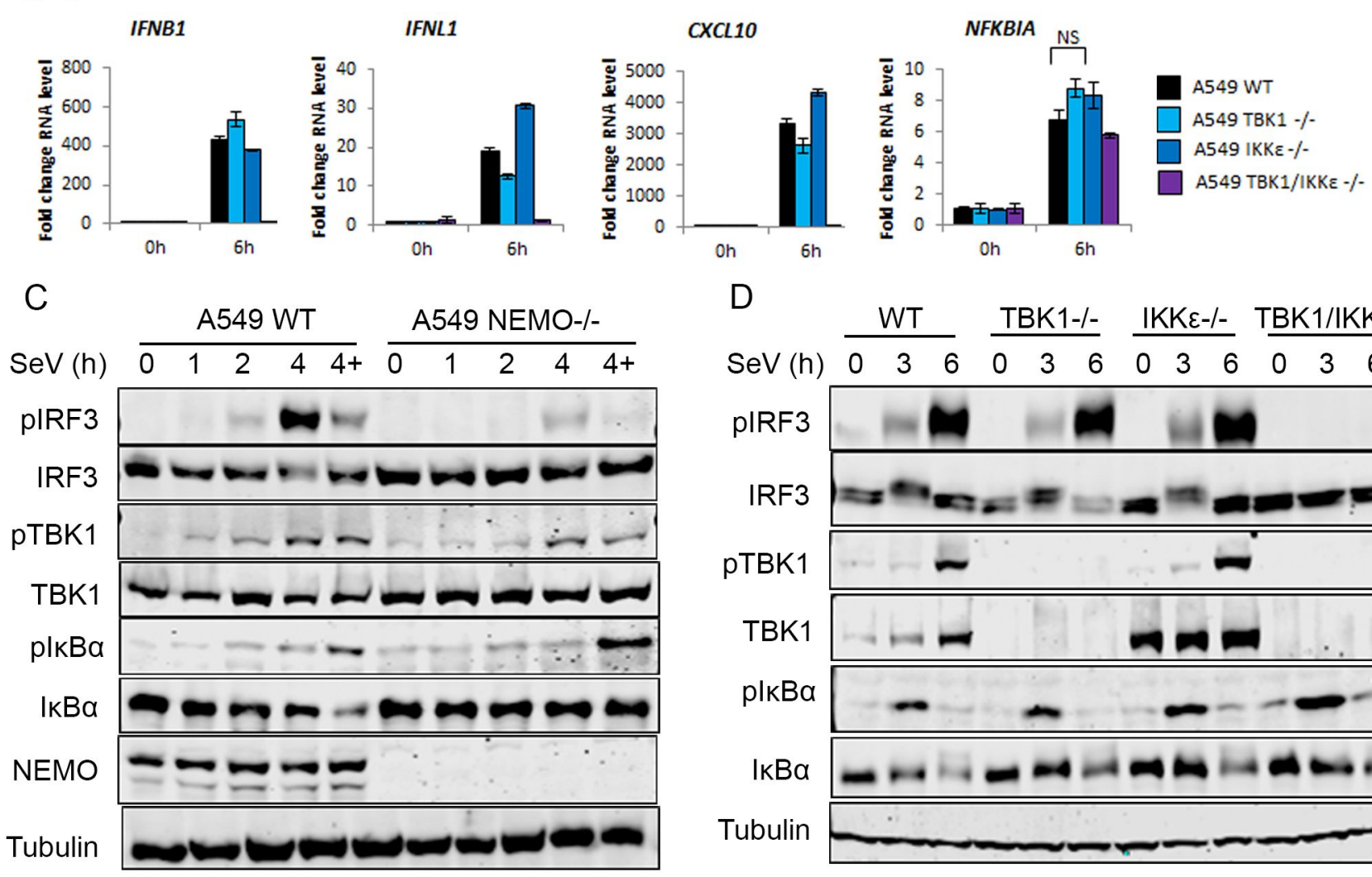

D

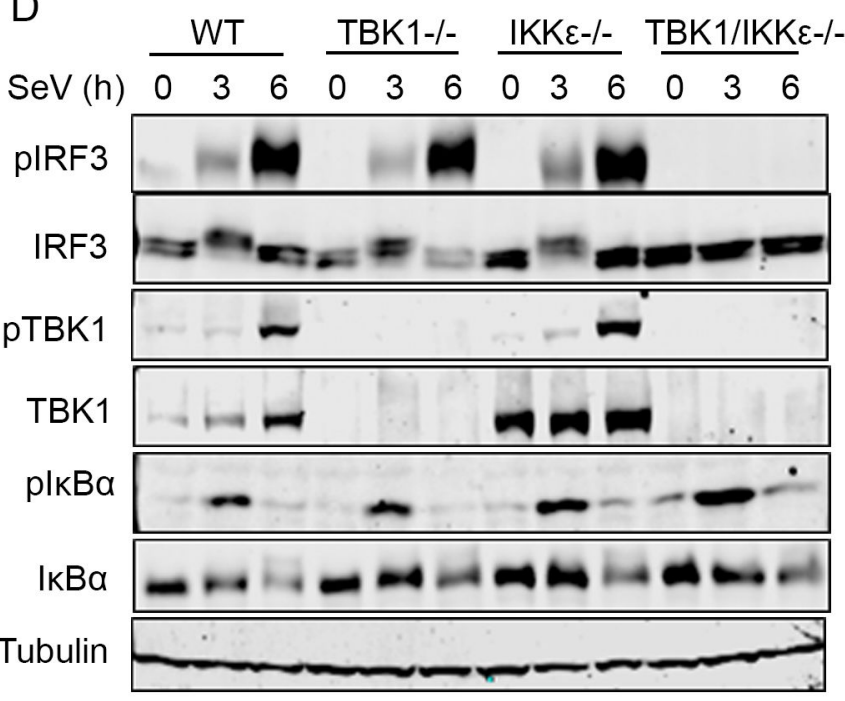

E TAP-NEMO

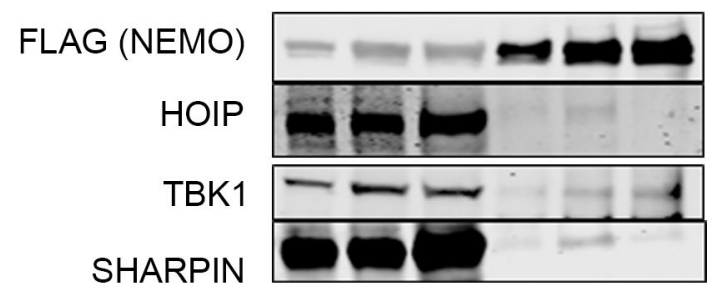

$\mathrm{F}$

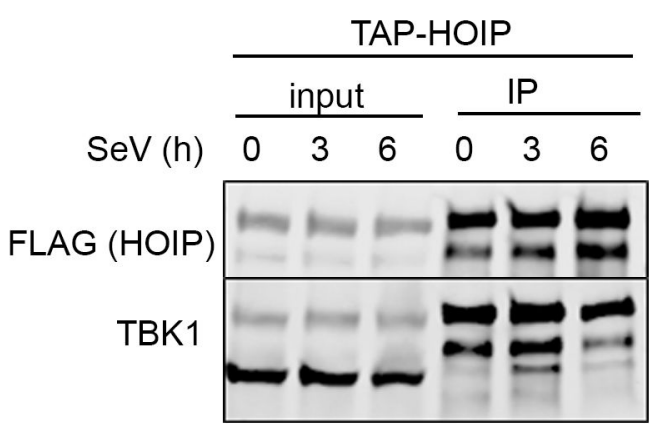




\section{Supplementary data}

\section{Supplementary Table 1. qPCR primer sequences used in this study.}

\begin{tabular}{|c|c|c|c|}
\hline Gene symbol & Gene name & $\begin{array}{l}\text { Primer } \\
\text { direction }\end{array}$ & Primer sequence \\
\hline \multirow[t]{2}{*}{ GAPDH } & \multirow{2}{*}{$\begin{array}{l}\text { glyceraldehyde-3- } \\
\text { phosphate } \\
\text { dehydrogenase }\end{array}$} & Forward & ACC CAG AAG ACT GTG GAT GG \\
\hline & & Reverse & TTC TAG ACG GCA GGT CAG GT \\
\hline \multirow[t]{2}{*}{ IFNB1 } & \multirow[t]{2}{*}{ interferon beta 1} & Forward & ACA TCC CTG AGG AGA TTA AGC A \\
\hline & & Reverse & GCC AGG AGG TTC TCA ACA ATA G \\
\hline \multirow[t]{2}{*}{ CXCL10 } & \multirow{2}{*}{$\begin{array}{l}\text { C-X-C motif chemokine } \\
\text { ligand } 10\end{array}$} & Forward & GTG GCA TTC AAG GAG TAC CTC \\
\hline & & Reverse & GCC TTC GAT TCT GGA TTC AGA CA \\
\hline \multirow[t]{2}{*}{ IFNL1 } & \multirow[t]{2}{*}{ interferon lambda 1} & Forward & CGC CTT GGA AGA GTC ACT CA \\
\hline & & Reverse & GAA GCC TCA GGT CCC AAT TC \\
\hline \multirow[t]{2}{*}{ ISG15 } & \multirow{2}{*}{$\begin{array}{l}\text { ISG15 ubiquitin like } \\
\text { modifier }\end{array}$} & Forward & AGC ATC TTC ACC GTC AGG TC \\
\hline & & Reverse & GAG GCA GCG AAC TCA TCT TT \\
\hline \multirow[t]{2}{*}{ ISG54/IFIT2 } & \multirow{2}{*}{$\begin{array}{l}\text { interferon induced } \\
\text { protein with } \\
\text { tetratricopeptide } \\
\text { repeats } 2\end{array}$} & Forward & CTG AAG AGT GCA GCT GCC TG \\
\hline & & Reverse & CAC TTT AAC CGT GTC CAC CC \\
\hline \multirow[t]{2}{*}{ NFKBIA } & \multirow[t]{2}{*}{ NFKB inhibitor alpha } & Forward & CTC CGA GAC TTT CGA GGA AAT \\
\hline & & Reverse & GCC ATT GTA GTT GGT AGC CTT \\
\hline \multirow[t]{2}{*}{ IL6 } & \multirow[t]{2}{*}{ interleukin 6} & Forward & ACA ACC ACG GCC TTC CCT ACT T \\
\hline & & Reverse & CAC GAT TTC CCA GAG AAC ATG TG \\
\hline
\end{tabular}

\section{Human qPCR primer sequences}

\begin{tabular}{|c|c|c|c|}
\hline $\begin{array}{l}\text { Gene } \\
\text { symbol }\end{array}$ & Gene name & $\begin{array}{l}\text { Primer } \\
\text { direction }\end{array}$ & Primer sequence \\
\hline \multirow[t]{2}{*}{ Hprt } & \multirow{2}{*}{$\begin{array}{l}\text { hypoxanthine guanine } \\
\text { phosphoribosyl transferase }\end{array}$} & Forwards & GTT GGA TAC AGG CCA GAC TTT GTT G \\
\hline & & Reverse & GAT TCA ACT TGC GCT CAT CTT AGG C \\
\hline \multirow[t]{2}{*}{ Ifnb1 } & \multirow[t]{2}{*}{ interferon beta 1} & Forwards & GCC TAG GTG AGG TTG ATC T \\
\hline & & Reverse & AGC TCC AAG AAA GCA CGA ACA T \\
\hline \multirow[t]{2}{*}{ Cxcl10 } & \multirow{2}{*}{$\begin{array}{l}\mathrm{C}-\mathrm{X}-\mathrm{C} \text { motif chemokine ligand } \\
10\end{array}$} & Forwards & ACT GCA TCC ATA TCG ATG AC \\
\hline & & Reverse & TTC ATC GTG GCA ATG ATC TC \\
\hline \multirow[t]{2}{*}{ Isg56/Ifit1 } & \multirow{2}{*}{$\begin{array}{l}\text { interferon-induced protein } \\
\text { with tetratricopeptide } \\
\text { repeats } 1\end{array}$} & Forwards & CTG AAG AGT GCA GCT GCC TG \\
\hline & & Reverse & CAC TTT AAC CGT GTC CAC CC \\
\hline
\end{tabular}


bioRxiv preprint doi: $h t t p s: / / d o i . o r g / 10.1101 / 2022.02 .24 .481814$; this version posted February 24, 2022. The copyright holder for this preprint (which was not certified by peer review) is the author/funder, who has granted bioRxiv a license to display the preprint in perpetuity. It is made available under aCC-BY-ND 4.0 International license.

\begin{tabular}{|l|c|l|l|}
\hline \multirow{2}{*}{ Isg15 } & ISG15 ubiquitin like modifier & Forwards & GCA AGC AGC CAG AAG CAG ACT CC \\
\cline { 3 - 4 } & & Reverse & CGG ACA CCA GGA AAT CGT TAC CCC \\
\hline \multirow{2}{*}{$\| 66$} & interleukin 6 & Forwards & GTA GCT ATG GTA CTC CAG AAG AC \\
\cline { 3 - 4 } & & Reverse & ACG ATG ATG CAC TTG CAG AA \\
\hline \multirow{2}{*}{$N f k b i a$} & NFKB inhibitor alpha & Forwards & CTG CAG GCC ACC AAC TAC AA \\
\cline { 3 - 4 } & & Reverse & CAG CAC CCA AAG TCA CCA AGT \\
\hline
\end{tabular}

Murine qPCR primer sequences 
Supplementary Table 2. Primary and secondary antibodies used for immunoblotting in this study.

\begin{tabular}{|c|c|c|c|}
\hline Antibody & Company & Code & Dilution/diluent \\
\hline RIG-I (D-12) & Santa Cruz & sc-376845 & 1:1000/TBST \\
\hline MAVS (E-3) & Santa Cruz & sc-166583 & 1:1000/TBST \\
\hline IKKgamma/NEMO (DA10-12) & Cell Signaling Technology & \#2695 & 1:1000/TBST \\
\hline IRF3 [EPR2418Y] & Abcam & ab68481 & 1:1000/TBST \\
\hline NAK/TBK1 [EP611Y] & Abcam & ab40676 & 1:1000/TBST \\
\hline IKB $\alpha$ (L35a5)- MEF & Cell Signaling Technology & \#4814 & $1: 1000 / T B S T$ \\
\hline$\alpha$-Tubulin (DM1A) & Millipore & $05-829$ & 1:5000/TBST \\
\hline ZIKV E protein & GeneTex & GTX133314 & 1:1000 PBST \\
\hline GAPDH & Sigma & G8795 & 1:20000 PBST \\
\hline IRF3 (phospho S386) [EPR2346] & Abcam & ab76493 & 1:1000/TBST \\
\hline Phospho-TBK1 (Ser172) D52C2 & Cell Signaling Technology & \#5483S & 1:1000/TBST \\
\hline Phospho-IкBa (Ser32/36) (5A5) & Cell Signaling Technology & \#9246 & 1:1000/TBST \\
\hline Phospho-IRF3 (Ser396) (4D4G) & Cell Signaling Technology & \#4947 & 1:500/TBST \\
\hline Ku70 [N3H10] & Abcam & ab3114 & $1: 1000 / T B S T$ \\
\hline IKKE (D61F9) XP & Cell Signaling Technology & \#3416 & 1:500/TBST \\
\hline HOIP (human; full length), pAb & Ubiquigent & $68-0013-100$ & $1: 1000 / T B S T$ \\
\hline RBCK1 (H-1) (HOIL-1) & Santa Cruz & sc-393754 & 1:1000/TBST \\
\hline SHARPIN & ProteinTech & 14626-1-AP & 1:1000/TBST \\
\hline Flag & Sigma & \#F7425 & 1:1000/TBST \\
\hline
\end{tabular}

\section{Primary antibodies used for western blotting}


bioRxiv preprint doi: https://doi org/10.1101/2022 02.24 .481814 ; this version posted February 24,2022 . The copyright holder for this preprint (which was not certified by peer review) is the author/funder, who has granted bioRxiv a license to display the preprint in perpetuity. It is made available under aCC-BY-ND 4.0 International license.

\begin{tabular}{|l|l|l|l|}
\hline Antibody & Company & Code & Dilution/diluent \\
\hline Goat anti-rabbit 680 RD & Li-Cor & $926-68071$ & $1: 10000 /$ TBST \\
\hline Goat anti-mouse 800 CW & Li-Cor & $926-32210$ & $1: 10000 /$ TBST \\
\hline Donkey anti-Goat 800-CW & Li-Cor & $926-32214$ & $1: 10000 /$ TBST \\
\hline
\end{tabular}

\section{Secondary antibodies used for western blotting}


bioRxiv preprint doi: https//doi org/10.1101/2022 0224.481814 : this version posted February 24,2022 . The copyright holder for this preprint (which was not certified by peer review) is the author/funder, who has granted bioRxiv a license to display the preprint in perpetuity. It is made available under aCC-BY-ND 4.0 International license.

\section{Supplementary Table 3. Antibodies used for PhosFlow analysis in this study}

\begin{tabular}{|l|l|l|l|}
\hline Antibody & Company & Code & Dilution/diluent \\
\hline $\begin{array}{l}\text { Phospho-IRF-3 (Ser396) (D6O1M) Rabbit mAb } \\
\text { (Alexa Fluor }{ }^{\circledR} 647 \text { Conjugate) }\end{array}$ & Cell Signaling & $\# 10327$ & $1: 25 /$ PBS $1 \%$ FCS \\
\hline PE Rabbit Anti- Active Caspase-3 Clone C92-605 & BD Pharmingen & 550821 & $1: 10 /$ PBS $1 \%$ FCS \\
\hline
\end{tabular}

Antibodies used for phos-flow analysis 
bioRxiv preprint doi: https://doi org/10.1101/2022 0224.481814 : this version posted February 24,2022 . The copyright holder for this preprint (which was not certified by peer review) is the author/funder, who has granted bioRxiv a license to display the preprint in perpetuity. It is made available under aCC-BY-ND 4.0 International license.

\section{Supplementary Table 4. Antibodies used for immunofluorescence analysis in this study}

\begin{tabular}{|l|l|l|l|}
\hline Antibody & Company & Code & Dilution \\
\hline IRF-3 (D83B9) Rabbit mAb & Cell Signaling & 4302 & $1: 200$ \\
\hline NF-אB p65 (C-20) & Santa Cruz & 312 & $1: 100$ \\
\hline E-Protein 4G2 & Fiocruz-PR, Brazil & - & $1: 100$ \\
\hline Human monoclonal antibody DV 18.4 & Beltramello et al. 2010 & - & $1: 100$ \\
\hline
\end{tabular}

Primary antibodies used for immunofluorescence

\begin{tabular}{|l|l|l|l|}
\hline Antibody & Company & Code & Dilution \\
\hline Goat anti-Rabbit IgG $(\mathrm{H}+\mathrm{L})$ Alexa Fluor 568 conjugated & Invitrogen & A-11011 & $1: 2000$ \\
\hline Goat anti-Mouse IgG $(\mathrm{H}+\mathrm{L})$ Alexa Fluor 488 conjugated & Invitrogen & A-11001 & $1: 2000$ \\
\hline Rabbit anti-Mouse IgG (H+L) Alexa Fluor 568 conjugated & Invitrogen & A-11061 & $1: 2000$ \\
\hline Goat anti-Human IgG (H+L) Alexa Fluor 488 conjugated & Invitrogen & A-11013 & $1: 2000$ \\
\hline
\end{tabular}

Secondary antibodies used for immunofluorescence 


\section{Supplementary Figure S1}
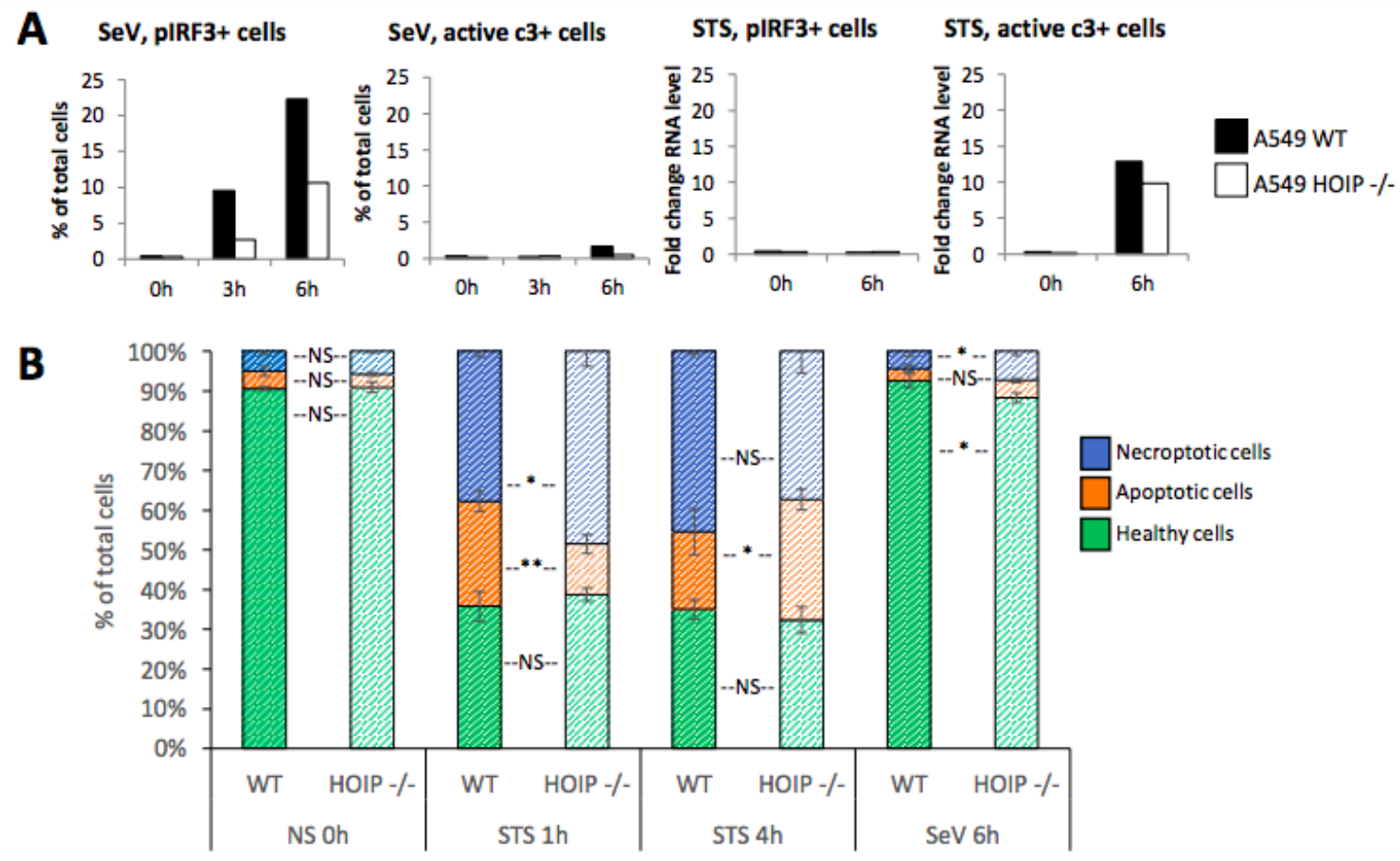

Supplementary Figure S1: Loss of HOIP does not result in RIG-I-driven cell death in A549 cells A) Phos-flow to measure cells expressing phospho-IRF3 and cleaved caspase 3 in A549 WT and HOIP -/- cells infected with SeVat 1:300 dilution. B) Nucleocounter (NC-250) Vitality Assay in A549 WT and HOIP -/- cells treated with staurosporine at $2 \mu \mathrm{M}$ or infected with SeV at 1:300 dilution for the indicated times. NS = not stimulated. 
bioRxiv preprint doi: https://doi org/10.1101/2022 02 24 481814 · this version posted February 24, 2022. The copyright holder for this preprint (which was not certified by peer review) is the author/funder, who has granted bioRxiv a license to display the preprint in perpetuity. It is made available under aCC-BY-ND 4.0 International license.

\section{Supplementary Figure S2}

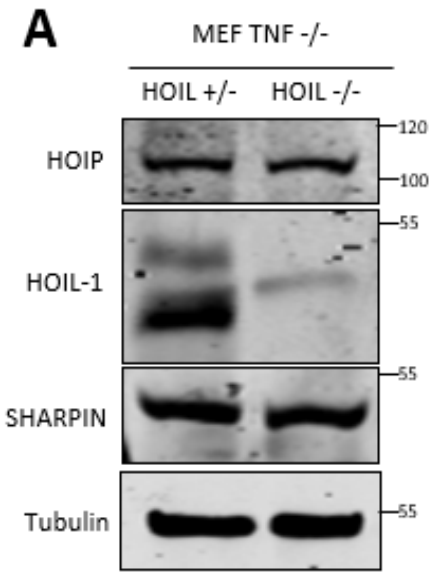

Supplementary Figure S2: Western blotting analysis of LUBAC components in MEF TNF -/HOIL +/- and TNF -/- HOIL -/- cells. 


\section{Supplementary Figure S3}

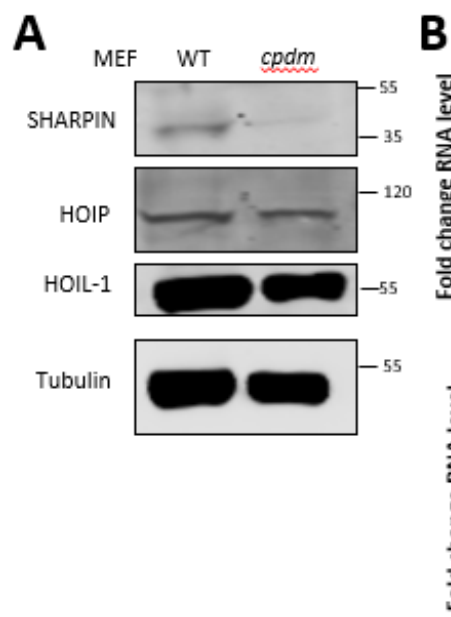

B SeV, Ifnb1

$\mathrm{SeV}, \mathrm{Cxcl} 10$

$\mathrm{SeV}, \operatorname{lsg} 15$

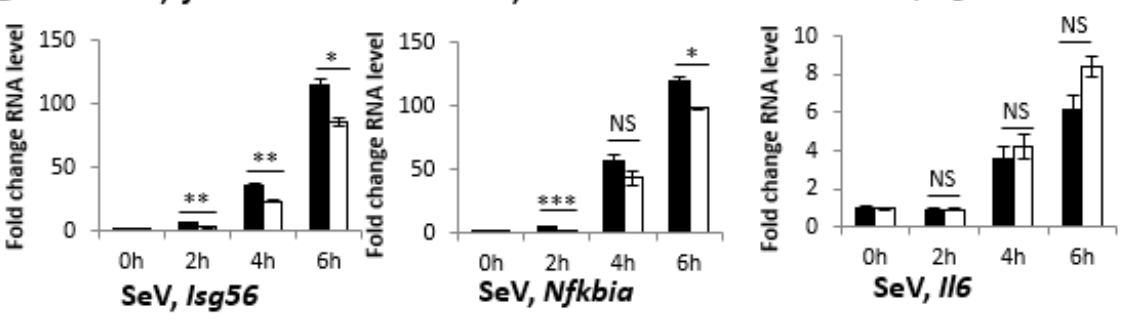

C 3p-hpRNA, Ifnb1

3p-hpRNA, Cxcl10
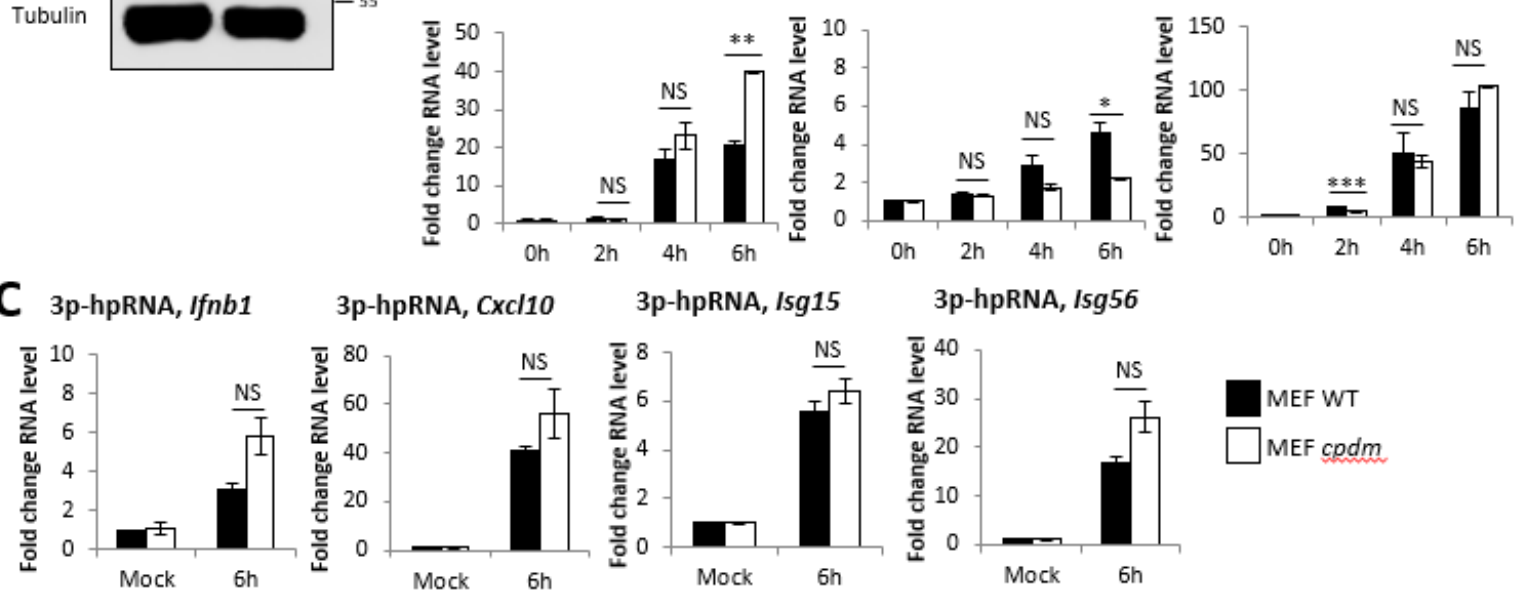

3p-hpRNA, Isg56

D Poly(I:C), Ifnb1

Poly(I:C), Cxc/10

Poly(I:C), Isg15

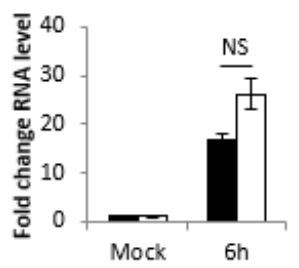

MEF WT

MEF $c p d m$
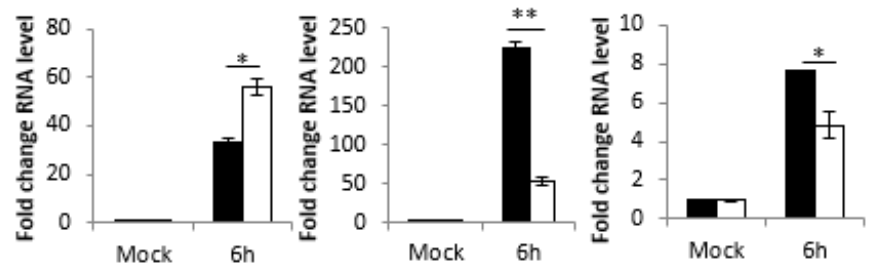

Poly(I:C), Isg56

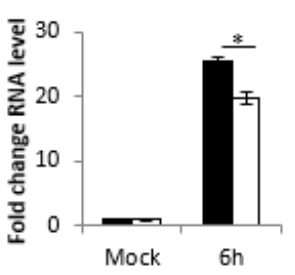

Supplementary Figure S3: SHARPIN is not required for RIG-I immune response to SeV and synthetic

RNAs in MEF cells A) Western blotting analysis of MEF WT and cpdm cells. qPCR to measure transcription of indicated genes in MEF WT and cpdm cells B) infected with SeV at a 1:300 dilution or transfected with C) $1 \mu \mathrm{g} 3 p$-hpRNA and D) $1 \mu \mathrm{g}$ Poly(l:C). 


\section{Supplementary Figure S4}
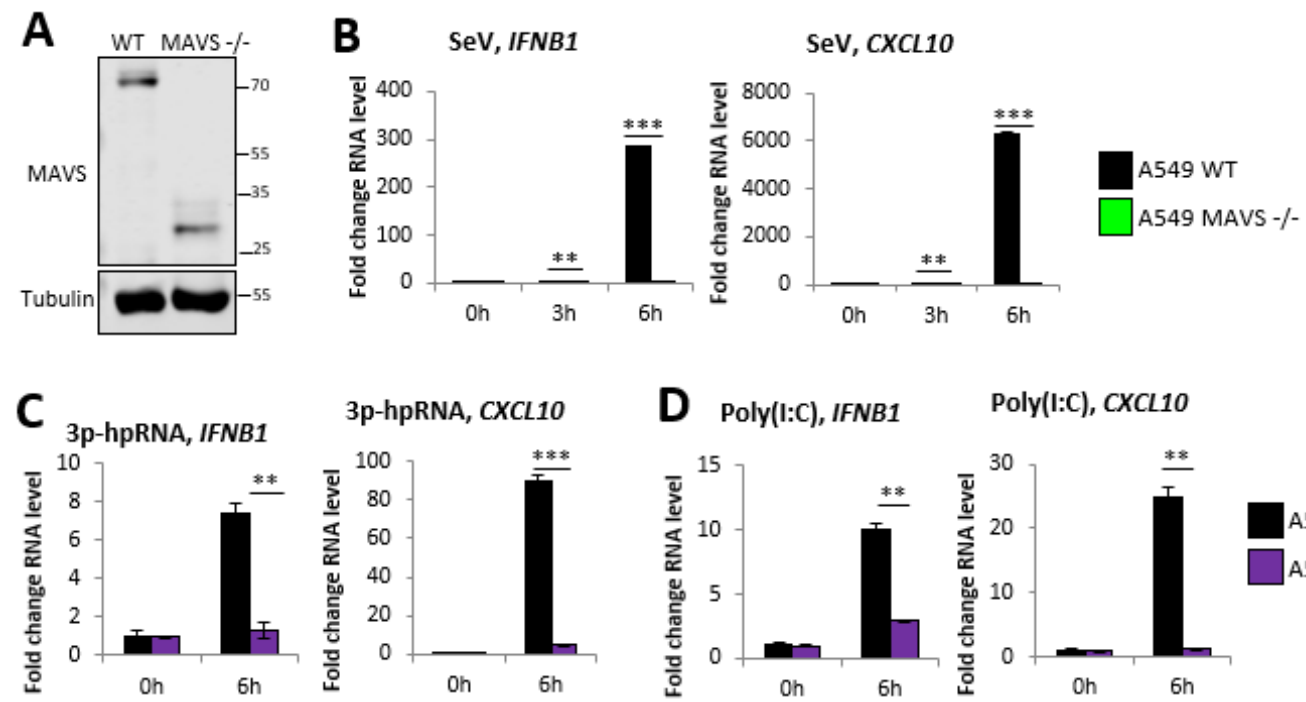

\section{3p-hpRNA, CXCL10}

D Poly(I:C), IFNB1

Poly(I:C), CXCL10
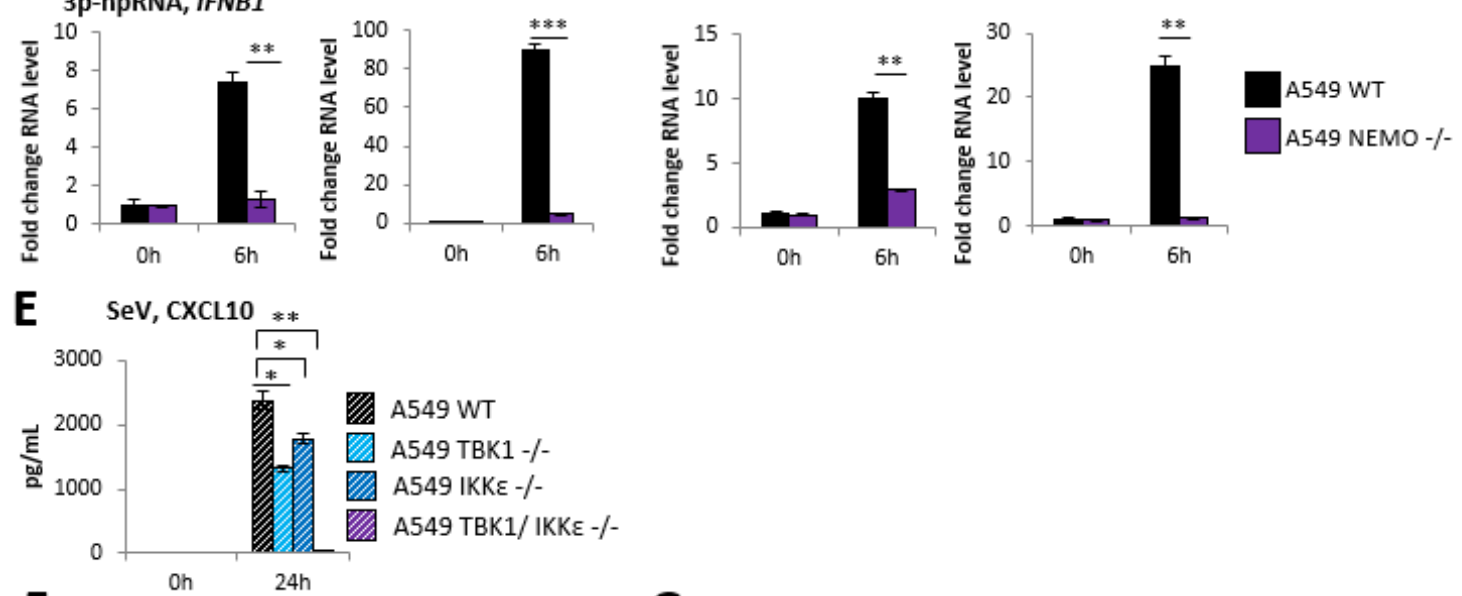

$\mathbf{F}$

3p-hpRNA, CXCL10

G
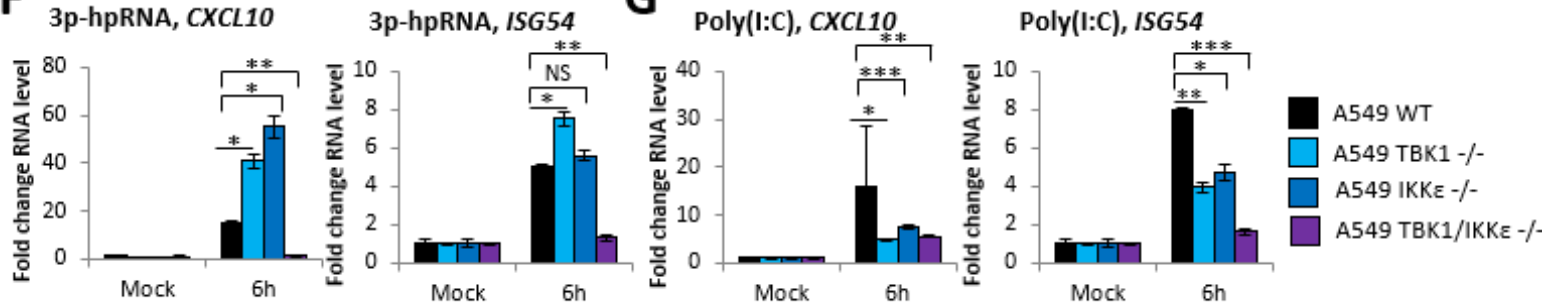

Supplementary Figure 4: Requirement of TBK1, IKKE, NEMO and MAVS in RIG-I signalling

A) Western blotting analysis of A549 WT and MAVS -/- cells. B) Transcription of indicated genes measured by qPCR in A549 WT and MAVS -/- cells infected with SeV at 1:300 dilution. qPCR to measure transcription of indicated genes in A549 WT and NEMO -/-cells transfected

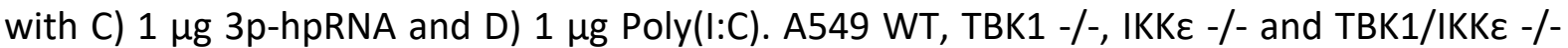
cells E) infected with SeV at 1:300 and ELISA to measure CXCL10 secretion, transfected with F) $1 \mu g$ 3p-hpRNA and G) $1 \mu \mathrm{g}$ Poly(I:C) and qPCR to measure transcription of indicated genes. 